\title{
NATURAL CHROMOSOME VARIATION IN LEONTODON
}

\author{
R. A. FINCH \\ Botany School, Oxford *
}

Received 28.ix.66

\section{INTRODUCTION}

THE chromosomes of Leontodon are rather small, but the material is not otherwise difficult. None the less, previous chromosome work on the genus is scanty and no large-scale population studies exist. This paper describes chromosome variation in the three British species, mainly from wild populations in Britain. They are L. autumnalis L. $n=6, L$. taraxacoides (Vill.) Mérat ( $=$ L. nudicaulis (L.) Banks emend. Porter ssp. taraxacoides (Vill.) Schinz et Thell. $=$ L. leysseri Beck) $n=4$, and $L$. hispidus L. $n=7$. All are sexual, self-incompatible perennials with different, but overlapping ecological and geographical distributions and are common over much of Britain and Europe. Some account is given of meiosis and breeding behaviour in normal and variant plants, the $\mathrm{F}_{\mathrm{I}}$ hybrid between $L$. taraxacoides and $L$. hispidus, and backcrosses. Further details may be found in Finch (rg66) and voucher specimens of various plant types mentioned have been deposited in the Fielding-Druce Herbarium at the Botany School, Oxford.

\section{MATERIALS AND METHODS}

\section{(i) Population samples}

Tables I -5 show the origins of the plants in the samples, omitting five $F_{I}$ hybrids between $L$. taraxacoides and L. hispidus found in four mixed populations from Berkshire, Oxfordshire and Buckinghamshire and a backcross found in a mixed population from Sussex. All British plants were wild adults. Most individuals from the same population grew about ten feet apart from one another in the field. It is obvious from morphology and karyotypes that few clones, if any, are duplicated. With the two exceptions noted in table 5 , all of the foreign plants were raised from wild seed. It is not known whether those from the same locality have parents in common. All plants were potted in John Innes No. 2 compost and kept in a greenhouse during winter and in a peatbed outside for the flowering season.

\section{(ii) Chromosome preparations}

Mitotic chromosomes were examined in root tips. Roots were pretreated for $I_{1}^{\frac{1}{2}}$ hours in 0.05 per cent. aqueous colchicine at room temperature, fixed overnight in $\mathrm{I}: 3$ acetic alcohol, hydrolysed for 6 minutes in N.HCl at $60^{\circ} \mathrm{C}$. and stained for I hour in Feulgen solution before treatment with tapwater for ro minutes. They were squashed in lacto-acetic orcein (Vosa. 196r).

Meiosis has been studied only in p.m.e.'s The clearest preparations were obtained by tapping out $\mathrm{I}-2$ whole, fresh florets in aceto-carmine or lacto-acetic orcein and U.K.

* Present address: Department of Plant Science, The University, Newcastle upon Tyne I, 
leaving them overnight to fix before squashing. Fixation overnight in fresh $\mathrm{I}: 3$ acetic alcohol, followed by Feulgen staining as for root tips was also used but caused stickiness, especially in triploids and aneuploids of $L$. taraxacoides and in species hybrids (plate $(d)$ ) and backcrosses.

Temporary slides both of root tips and of p.m.c.'s were made permanent in euparal after the coverslips had been separated from the slides by dry ice treatment.

TABLE 1

L. autumnalis: numbers of British populations and plants sampled. Variant chromosomes present are in brackets

\begin{tabular}{|c|c|c|c|c|}
\hline \multirow{3}{*}{$\begin{array}{l}\text { Region and } \\
\text { county }\end{array}$} & \multirow{3}{*}{$\begin{array}{l}\text { No. of } \\
\text { pops. }\end{array}$} & \multicolumn{3}{|c|}{ No. of plants } \\
\hline & & \multirow{2}{*}{ Normal } & \multicolumn{2}{|c|}{ Variant in } \\
\hline & & & Chrs. C or F & Chrs. A or E \\
\hline \multirow{5}{*}{$\begin{array}{l}\text { South-east } \\
\text { Sussex } \\
\text { Berks. } \\
\text { Oxon. } \\
\text { Warwicks. }\end{array}$} & & & & \\
\hline & 8 & 3 & I $6\left(\mathrm{C}_{2}, \mathrm{~F}_{2}, \mathrm{~F}_{3}\right)$ & $\ldots$ \\
\hline & 3 & 2 & $\mathrm{I}\left(\mathrm{F}_{2}\right)$ & $\ldots$ \\
\hline & 2 & $\ldots$ & $2\left(\mathrm{C}_{2}, \mathrm{~F}_{3}\right)$ & ... \\
\hline & 2 & 8 & $4\left(\mathrm{~F}_{2}\right)$ & $\cdots$ \\
\hline \multicolumn{5}{|l|}{ North-west } \\
\hline Caerns. & 2 & 2 & $\cdots$ & \\
\hline Anglesey & I & 2 & I $\left(\mathrm{C}_{2}\right)$ & $\ldots$ \\
\hline Yorks. & I & $\cdots$ & $2\left(\mathrm{C}_{2}, \mathrm{~F}_{3}\right)$ & $\ldots$ \\
\hline Westmorland & I & 6 & $2\left(\mathrm{C}_{2}\right)$ & $\ldots$ \\
\hline Argyll & 2 & 29 & I ( $\left.\mathrm{C}_{2}\right)$ & $\begin{array}{c}2\left(\mathrm{E}_{1} \cdot 3 \& \mathrm{~A}-\mathrm{E}\right. \\
\text { interch. pls.) }\end{array}$ \\
\hline Ross & I & 7 & ... & $\ldots$ \\
\hline
\end{tabular}

TABLE 2

L. autumnalis: numbers of plants sampled (as seeds) from 5 European populations. Variant chromosomes present are in brackets

\begin{tabular}{|c|c|c|c|c|c|}
\hline \multirow{4}{*}{ Plants } & \multicolumn{2}{|c|}{ C. Europe } & \multicolumn{3}{|c|}{ N. Europe } \\
\cline { 2 - 6 } & Czechoslovakia & Austria & \multicolumn{2}{|c|}{ Finland } & Lithuania \\
\cline { 2 - 6 } & Tábor & Vienna & Uusimaa & Pohjois-Häme & Kaunas \\
\hline $\begin{array}{c}\text { Normal } \\
\text { Variant }\end{array}$ & $\mathrm{I}_{\left(\mathrm{C} 2, \mathrm{E}_{2}\right)}$ & $\mathrm{I}\left(\mathrm{C}_{2}\right)$ & $\mathbf{2}\left(\mathrm{C}_{2}, \mathrm{~F}_{3}\right)$ & $5\left(\mathrm{C}_{2}, \mathrm{~F}_{3}\right)$ & $\ldots$ \\
\hline
\end{tabular}

\section{(iii) Pollinations}

Crossing was done by brushing the two parental flower heads together on each of the three or four days when they were open and was inevitably reciprocal. Pollinating insects were kept away by paper bags clipped over the flower heads. Emasculation before crossing was unnecessary, for all the several plants of each species and the hybrid tested were nearly or quite self-incompatible. There was no sign of apomixis and crossing was often confirmed by the inheritance of marker chromosomes through pollen. 
TABLE 3

L. taraxacoides: numbers of British populations and plants sampled, excluding I2 diploids from Sussex and 7 from Oxon. not scored for structural variation

\begin{tabular}{|c|c|c|c|c|c|c|}
\hline \multirow{4}{*}{ County } & \multirow{4}{*}{$\begin{array}{l}\text { No. of } \\
\text { pops. }\end{array}$} & \multicolumn{5}{|c|}{ No. of plants } \\
\hline & & \multirow{3}{*}{ Normal } & \multicolumn{4}{|c|}{ Variant } \\
\hline & & & \multirow{2}{*}{$\mathrm{BB}^{\prime}$} & \multicolumn{2}{|c|}{$3^{x}$} & \multirow{2}{*}{$\begin{array}{c}\mathrm{B}-\mathrm{C} \\
\text { interchange }\end{array}$} \\
\hline & & & & BBB & $\mathrm{BBB}^{\prime}$ & \\
\hline Cornwall & 3 & 3 & $\cdots$ & $\ldots$ & $\ldots$ & I \\
\hline Dorset & I & 2 & I & $\ldots$ & $\ldots$ & $\ldots$ \\
\hline Sussex & I I & 27 & 4 & I & 2 & $\cdots$ \\
\hline Berks. & 2 & 4 & $\cdots$ & $\cdots$ & $\cdots$ & $\cdots$ \\
\hline Oxon. & I & 4 & $\dddot{q}$ & $\cdots$ & $\cdots$ & $\cdots$ \\
\hline Bucks. & I & 7 & 8 & $\cdots$ & $\cdots$ & $\cdots$ \\
\hline $\begin{array}{l}\text { Warwicks. } \\
\text { Anglesey }\end{array}$ & I & $\begin{array}{l}\text { I } \\
8\end{array}$ & $\cdots$ & $\cdots$ & $\cdots$ & $\cdots$ \\
\hline Anglesey & & & $\cdots$ & $\cdots$ & $\cdots$ & $\cdots$ \\
\hline
\end{tabular}

TABLE 4

L. hispidus: numbers of British populations and plants sampled

\begin{tabular}{|c|c|c|c|c|c|}
\hline \multirow{3}{*}{ County } & \multirow{3}{*}{$\begin{array}{l}\text { No. of } \\
\text { pops. }\end{array}$} & \multicolumn{4}{|c|}{ No. of plants } \\
\hline & & \multirow{2}{*}{ Normal } & \multicolumn{3}{|c|}{ Variant } \\
\hline & & & $\mathrm{C}_{1} .2$ & $\mathrm{G}_{1} \cdot 2$ & $3^{x}$ \\
\hline Sussex & 5 & 20 & $\ldots$ & $\ldots$ & $\ldots$ \\
\hline Berks. & 4 & I3 & $\ldots$ & $\ldots$ & I \\
\hline Oxon. & I & $\ldots$ & I & $\ldots$ & $\ldots$ \\
\hline Bucks. & I & 3 & $\cdots$ & $\ldots$ & $\cdots$ \\
\hline Glos. & I & 2 & $\ldots$ & $\ldots$ & $\ldots$ \\
\hline Cambs. & I & 3 & $\ldots$ & $\ldots$ & $\ldots$ \\
\hline Derby & I & I & $\ldots$ & $\ldots$ & $\ldots$ \\
\hline Westmorland & 2 & I 3 & $\ldots$ & I & $\ldots$ \\
\hline
\end{tabular}

\section{TABLE 5}

L. hispidus: numbers of plants sampled (as seeds) from 6 European populations. Variant karyotypes are in brackets

\begin{tabular}{|c|c|c|c|c|c|c|}
\hline \multirow[b]{2}{*}{ Plants } & Finland & \multicolumn{2}{|c|}{ Czechoslovakia } & Germany & Switzerland & Austria \\
\hline & Pohjois-Karjala & Tábor & Brno & $\begin{array}{c}\text { Halle } \\
\text { Bot. Gdn. }\end{array}$ & Zurich & Vienna \\
\hline $\begin{array}{l}\text { Normal } \\
\text { Variant }\end{array}$ & $\begin{array}{l}\text { Io } \\
\cdots\end{array}$ & $\begin{array}{c}\text { I } \\
\cdots\end{array}$ & $\begin{array}{c}\mathrm{I} \\
\cdots\end{array}$ & $I\left(\mathrm{~F}_{1} \cdot 2\right)$ & $\begin{array}{c}8 \\
\text { I }\left(A_{1} \cdot 2\right)\end{array}$ & $\begin{array}{l}2^{*} \\
\cdots\end{array}$ \\
\hline
\end{tabular}

* One plant was an adult, not a seed sample. 


\section{(iv) Illustrations}

Unless otherwise stated, the scale of all figs. is $\times 3,000$. The relative lengths of the chromosome arms of $L$. autumnalis and $L$. hispidus in figs. I and 4 are based on camera lucida measurements of ten different metaphase chromosomes of each type at similar stages of contraction. Measurements for $L$. taraxacoides were made on chromosomes which were slightly less contracted than those in L. hispidus, as they were then longer and easier to measure. These values were scaled down $(\times 0 \cdot 86)$ for fig. 4 (a) to give the same size relative to the $L$. hispidus chromosomes as in the $\mathbf{F}_{\mathbf{I}}$ hybrid. The resulting inaccuracies in arm length ratios look negligible.

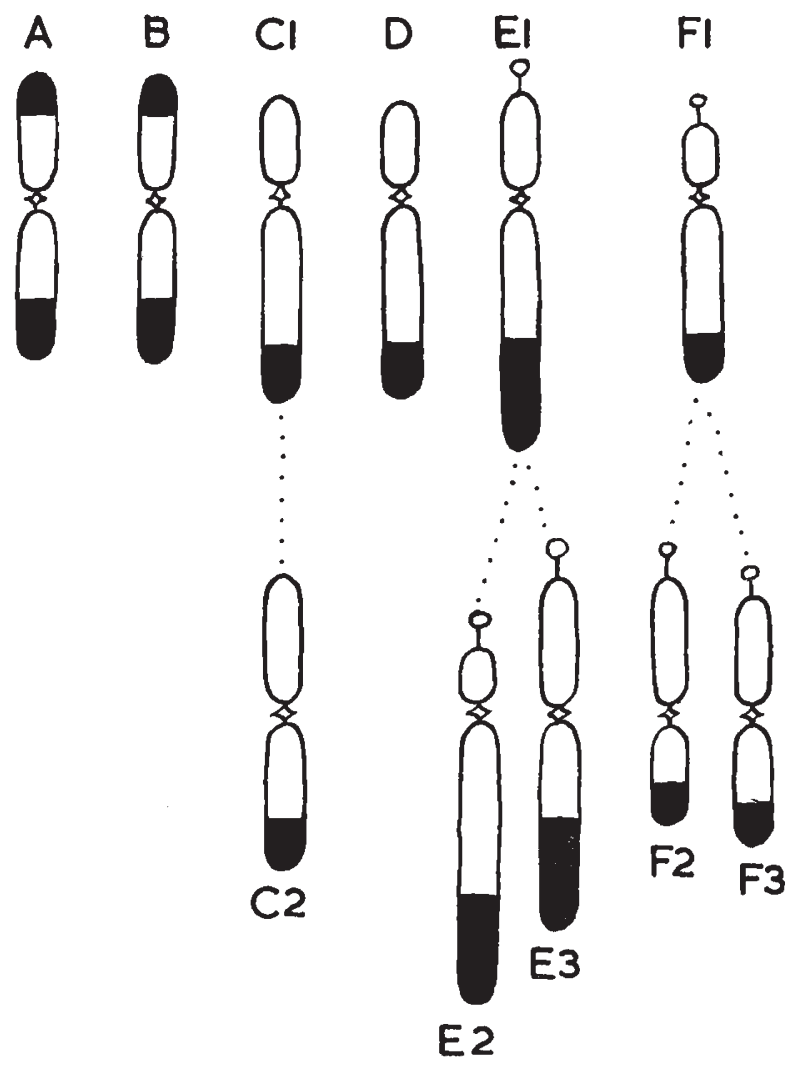

Fig. I.-L. autumnalis: normal haploid set with variant types below. Chiasmata occur only in the segments drawn solid. $\times 8,000$.

\section{(v) Conventions}

Variant plants are referred to by the members of the variant chromosome pairs. Thus an "AI.2" plant is a heterozygote with chromosomes AI and A2 but otherwise normal, and a " $\mathrm{C}_{1.3} \mathrm{Gr}_{1.2}$ " plant is a heterozygote with chromosomes $\mathrm{C}_{1}$ and $\mathrm{C}_{3}$,

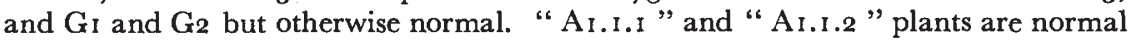
except in having an extra chromosome each (chromosomes $\mathrm{A}_{1}$ and A2, respectively). In L. taraxacoides, " $\mathrm{BBB}$ " triploids are normal and " $\mathrm{BBB}^{\prime}$ " triploids have two normal forms and one $B$ " form of chromosome B. An "A-E in erchange" plant is heterozygous for an interchange between chromosomes $\mathrm{A}$ and $\mathrm{E}$.

Certain chromosomes are so similar that they cannot be reliably distinguished. These include $\mathrm{A}, \mathrm{B}$ and $\mathrm{C}_{2}$, and $\mathrm{C}_{1}$ and $\mathrm{D}$ in L. autumnalis; $\mathrm{B}, \mathrm{C}$ and $\mathrm{D}$ in L. taraxacoides; and $\mathrm{A}$ and $\mathrm{B}$, and $\mathrm{E}, \mathrm{F}$ and $\mathrm{G}$ in L. hispidus. Likewise, one cannot distinguish 
$\begin{array}{llllll}A & B & C & D & E & F\end{array}$
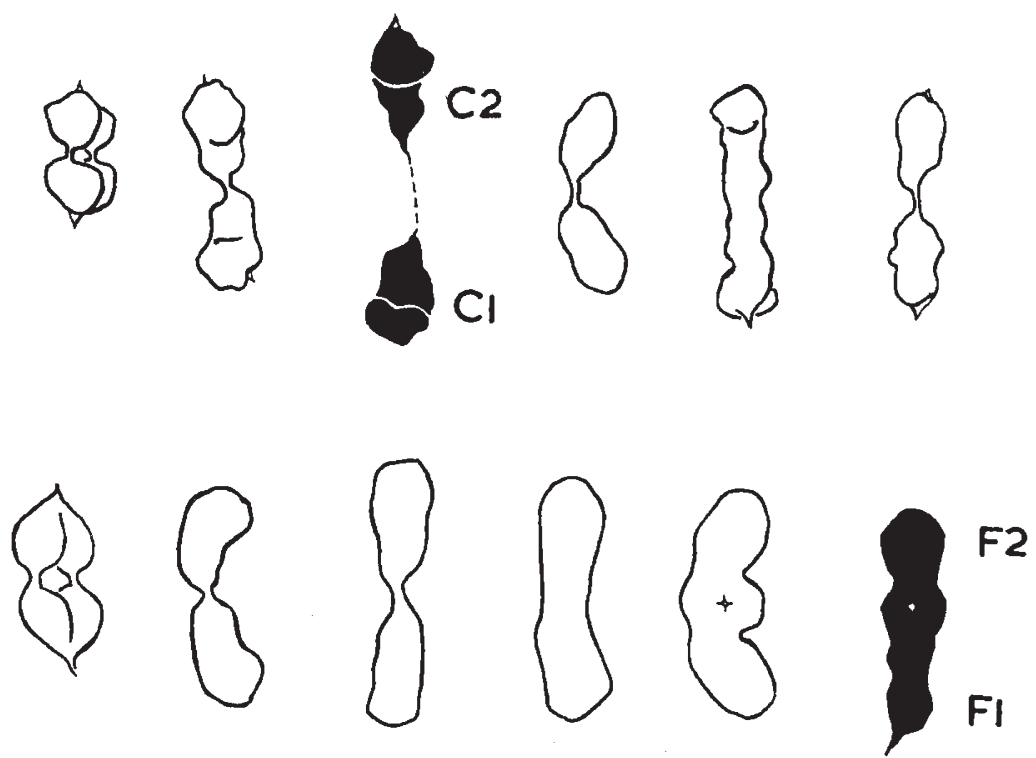

FIG. 2.-L. autumnalis: MI in $\mathrm{Cr}_{1.2}$ and $\mathrm{F}_{\mathrm{I} .2}$ plants.
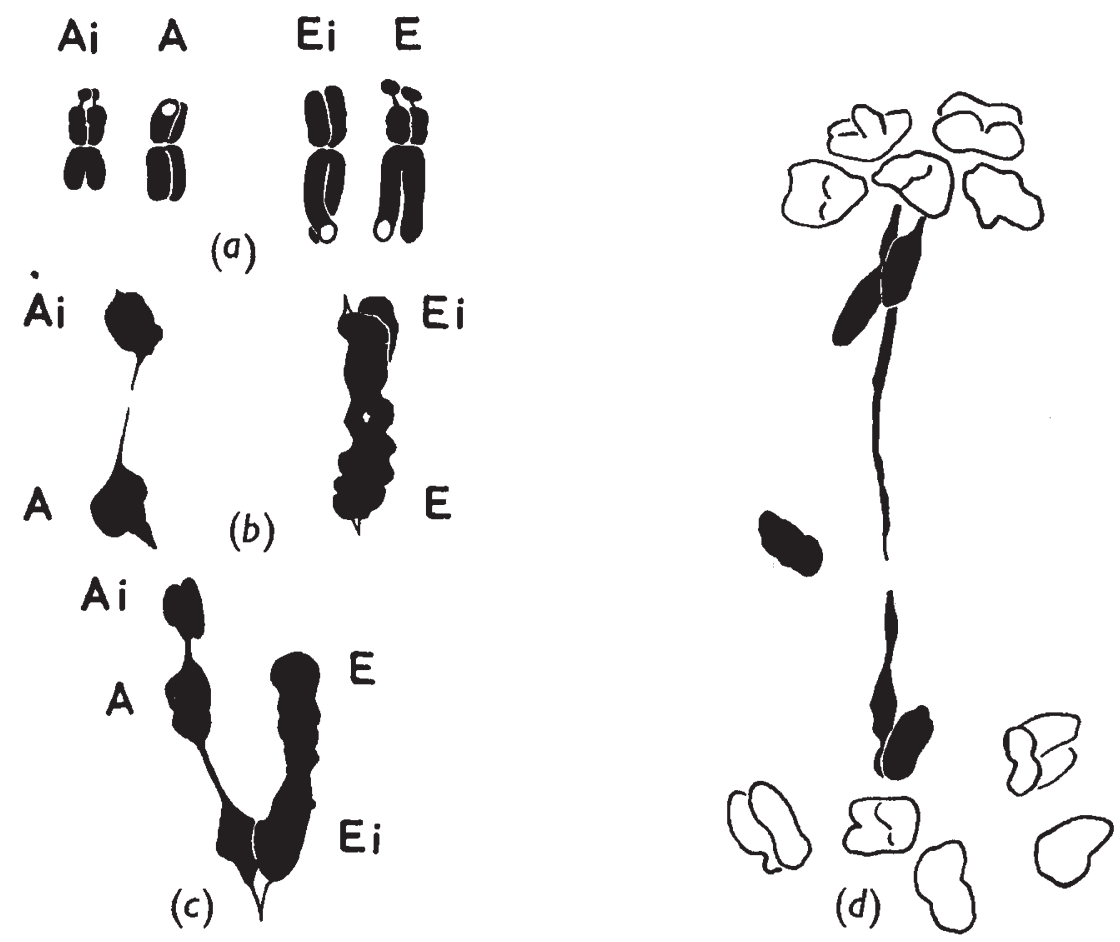

FIG. 3. - L. autumnalis: $(a)-(c)$ A-E interchange complex: $(a)$ mitosis, $(b) 2$ II at MI, (c) chain of 4 at MI. (d) AI bridge and fragment in Cr.3 plant. 
between the two arms of a metacentric. L. taraxacoides chromosome B is distinguishable at meiosis in diploids. Variants among these chromosomes are assigned to one

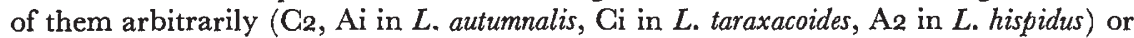
according to probability ( $\mathrm{Bi}$ in $L$. taraxacoides, $\mathrm{F}_{2}, \mathrm{G}_{2}, \mathrm{G}_{3}$ in $L$. hispidus). In tables, results for indistinguishable chromosomes are given as mean values of pooled data.
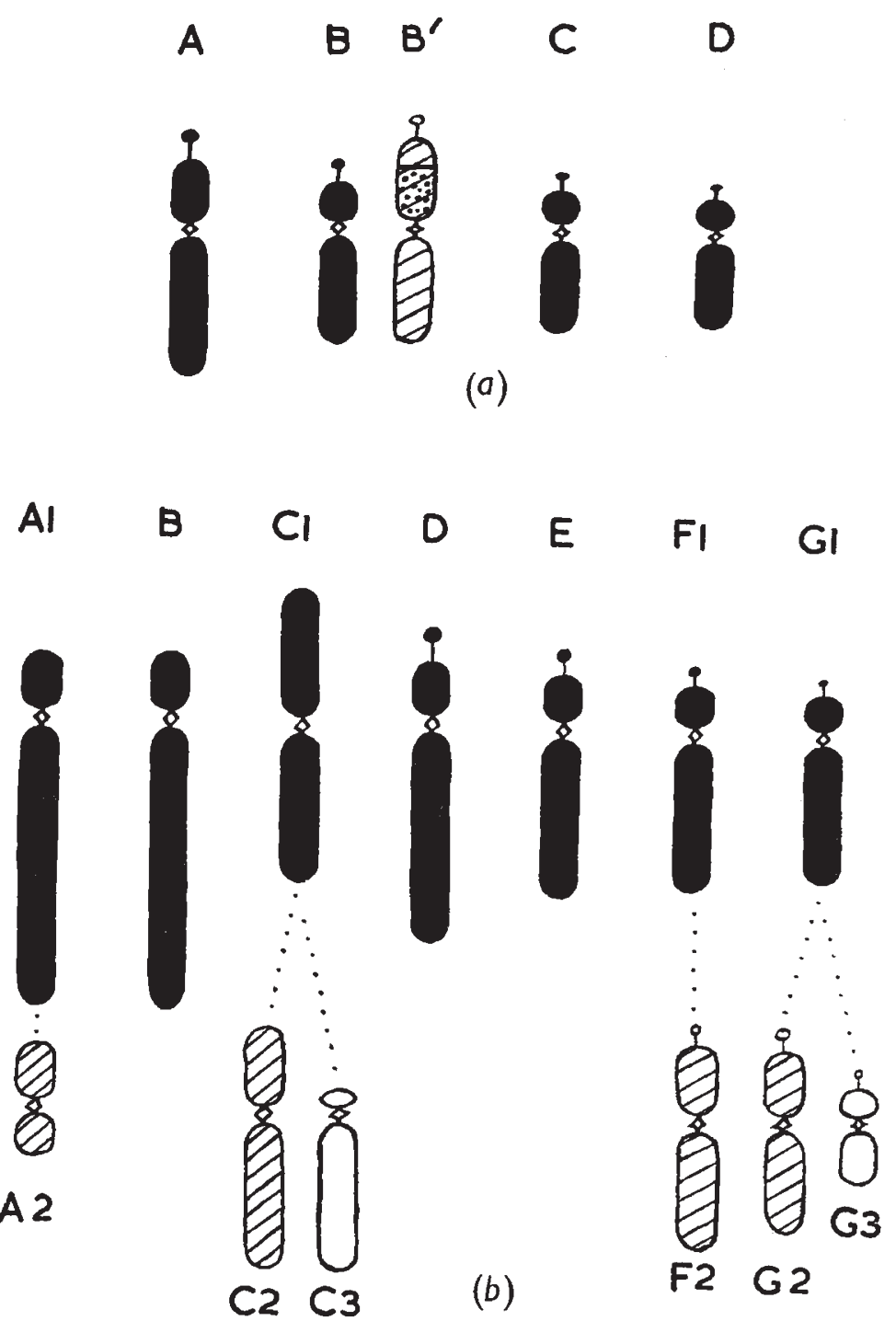

FIG. 4. - L. taraxacoides $(a)$ and L. hispidus (b): normal haploid chromosomes (solid), wild variants (striped) and variants from experimental crosses (blank). The extra segment in chromosome $\mathrm{B}^{\prime}$ is dotted in $(a) . \times 8,000$

\section{NORMAL CHROMOSOME COMPLEMENTS}

The normal haploid sets are shown in figs. I and 4. Secondary constrictions occur in most chromosomes but are so difficult to display consistently that they have been ignored except for those marking satellites. At prophase, the proximal regions of all chromosomes are 
more condensed than the distal, so making the ratio, length of long arm: length of short arm, greater than it is at metaphase.

\section{CHROMOSOME VARIATION IN THE PURE SPECIES}

\section{(i) Gain or loss of chromatin}

Variation in satellite size occurs throughout the ranges of all three species and plants often appear heterozygous for satellite size in all satellite pairs. Medium-sized satellites are the commonest in all chromosomes, but there is probably continuous variation from minute specks invisible in most cells to large blocks half the size of the arm bearing them or more. Chromosomes $\mathrm{F}_{2}$ and $\mathrm{F}_{3}$ in L. autumnalis are exceptional in having satellites of constant size but this may be because only a few have been sampled. Satellites occur as tandem forms in some cells. Many plants appear to have fewer than the expected number of satellites. This is presumably because minute satellites have been overlooked.

In L. taraxacoides, several plants have one chromosome B present as the $\mathrm{B}^{\prime}$ form (fig. $4(a)$ ). This differs from chromosome $\mathrm{B}$ only in having an extra segment in the short arm. It is not yet known homozygous, perhaps because too few plants have been sampled. Although fairly large, the extra segment never forms chiasmata in diploids, aneuploids or triploids. Either it is a translocated or duplicated segment which is prevented from effective pairing by inversion relative to the centromere or else it is not homologous with any other segment in the genome. In the latter case, it could be a relic of chromosome diminution or have come from another species following hybridization and backcrossing.

Deficiencies occur only in L. hispidus and all are heterozygous (fig. $4(b)$ ).

\section{(ii) Pericentric rearrangement}

In L. autumnalis, chromosomes $\mathrm{C}_{2}, \mathrm{~F}_{2}$ and $\mathrm{F}_{3}$ (fig. I) are variant forms which can be heterozygous with the normal forms or rarely homozygous. They could come from translocations ( $c f$. White and Morley, I955) but are most simply explained as pericentric inversions, one in chromosome $\mathbf{C}$ and two in chromosome $\mathbf{F}$. Some apparent $\mathbf{C}_{2}$ chromosomes may be variants of chromosome $\mathrm{D}$, but the plant with two variant metacentric chromosomes which was examined critically at meiosis was a homozygote, not a double heterozygote. This suggests that only one of chromosomes $\mathbf{C}$ and $\mathbf{D}$ has a metacentric variant, for one should find a double heterozygote before either homozygote if two independent variants occur.

Chromosomes $\mathbf{C}$ and $\mathbf{F}$ vary independently. Ten of the eighteen possible karyotypes have been found wild (table 6) and probably all exist.

Chromosome $\mathrm{E}$ also has two forms showing a centric shift (fig. I). 
In L. hispidus, heterozygotes for forms of chromosomes $\mathrm{F}$ and $\mathrm{G}$ showing centric shift have been found (fig. $4(b)$ ).

(iii) Paracentric inversion

Bridges and fragments at meiotic anaphase are taken as evidence of crossing-over within paracentric inversions. In L. autumnalis, the $\mathrm{E}_{\mathrm{I} .2}$ and $\mathrm{E}_{\mathrm{I}} .3$ plants have an AI bridge and fragment (fig. $3(d)$ ) in a few p.m.c.'s ( $<\mathrm{I}$ per cent.). The chromosomes involved are not always identifiable. Their lengths and rarity show that if the bridges

TABLE 6

L. autumnalis: regional frequencies of karyotypes differing in chromosomes $C$ or $F$

\begin{tabular}{|c|c|c|c|c|c|c|}
\hline \multirow{3}{*}{ Locality } & \multicolumn{6}{|c|}{ Chromosome constitution } \\
\hline & \multirow{2}{*}{ C } & \multicolumn{5}{|c|}{$\mathbf{F}$} \\
\hline & & I.I & 1.2 & I. 3 & 2.2 & $3 \cdot 3$ \\
\hline S.E. Britain & $\begin{array}{l}\text { I.I } \\
1.2 \\
2.2\end{array}$ & $\begin{array}{r}\text { I3 } \\
3 \\
3\end{array}$ & $\begin{array}{l}7 \\
4 \\
0\end{array}$ & $\begin{array}{l}\text { I } \\
3 \\
0\end{array}$ & $\begin{array}{l}\text { I } \\
0 \\
\text { I }\end{array}$ & $\begin{array}{l}0 \\
0 \\
0\end{array}$ \\
\hline N.W. Britain & $\begin{array}{l}\text { I.I } \\
\text { I.2 }\end{array}$ & $\begin{array}{r}4^{6} \\
5\end{array}$ & $\begin{array}{l}0 \\
0\end{array}$ & $\begin{array}{l}\text { I } \\
0\end{array}$ & $\begin{array}{l}0 \\
0\end{array}$ & $\begin{array}{l}0 \\
\text { o }\end{array}$ \\
\hline C. Europe & $\begin{array}{l}\text { I.I } \\
\text { I.2 }\end{array}$ & $\begin{array}{l}7 \\
1\end{array}$ & $\begin{array}{l}I^{*} \\
0\end{array}$ & $\begin{array}{l}0 \\
0\end{array}$ & $\begin{array}{l}0 \\
0\end{array}$ & $\begin{array}{l}0 \\
0\end{array}$ \\
\hline N. Europe & $\begin{array}{l}\text { I.I } \\
\text { I. }\end{array}$ & $\begin{array}{r}\mathrm{I} 2 \\
\mathrm{I}\end{array}$ & $\begin{array}{l}0 \\
0\end{array}$ & $\begin{array}{l}4 \\
I\end{array}$ & $\begin{array}{l}0 \\
0\end{array}$ & $\begin{array}{l}\text { I } \\
0\end{array}$ \\
\hline
\end{tabular}

* EI. 2 FI. 2 plant.

and fragments do result from inversion crossing-over and not spontaneous breakage and reunion, the inverted segments they reveal must be short and partly within regions immune from chiasma-formation.

In $L$. taraxacoides, the A chromosomes in an otherwise normal triploid may form a bridge and fragment at $\mathrm{AI}$ and so may one of the A or B pairs in the GI.2 plant of L. hispidus. These bridges are too frequent to have been caused by spontaneous breakage and reunion. An aneuploid of $L$. taraxacoides also may show an inversion bridge formed by two of the B-D Chromosomes (fig. $6(b)$ ). The inversion concerned may have come from a wild plant or it may have arisen during the crosses from which the aneuploid was produced.

\section{(iv) Interchange and triploidy}

Interchange heterozygotes occur in all three species (figs. $3(a)-(c)$, $5(c)-(e), 7(c))$. The interchange in L. hispidus may have come from an otherwise normal wild plant or it may have arisen during a cross (see "Spontaneous Chromosome Mutation"). 
In L. taraxacoides, one normal and two $\mathrm{BBB}^{\prime}$ triploids occurred and a normal triploid was also found in L. hispidus.

\section{MEIOSIS IN THE THREE SPECIES \\ (i) General}

At prophase, the satellite threads are often associated with nucleoli. Diakinesis chromosomes are diffuse, with the proximal regions more
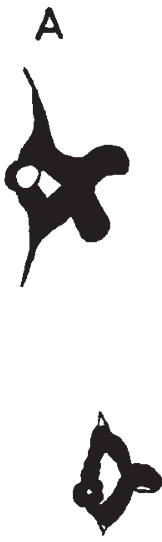

B

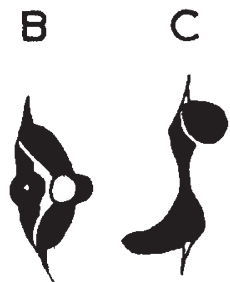

(a)

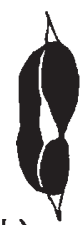

(b)
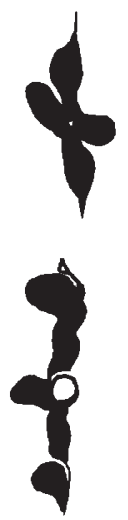

\section{$\mathrm{Bi} \mathrm{Ci} \quad \mathrm{B} \quad \mathrm{C}$

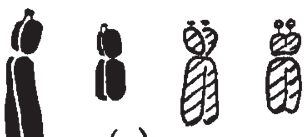 \\ (c)}

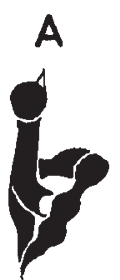

B

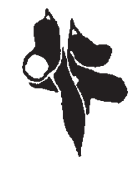

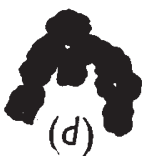

C

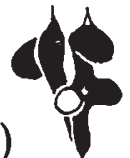

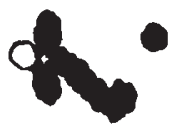

(e)

D

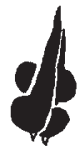

FIG. 5.-L. taraxacoides: (a) $\mathrm{MI}$ in normal $2 x$. (b) $3 \mathrm{BB}^{\prime}$ bivalents from different cells, that on the left fixed in aceto-carmine, the other 2 fixed in acetic alcohol. $(c)-(e)$ B-C interchange complex: $(c)$ mitosis, $(d)$ chain of 4 at MI, $(e)$ chain of $3+\mathrm{I}$ at MI. $(f) 4$ III at MI in normal $3 x$.

condensed than the distal, as at mitotic prophase. This aids the identification of chromosomes and pairing segments, especially in variants of $L$. autumnalis.

The position and number of chiasmata are the same at MI as at diakinesis.

AI bridges persist into AII, as the p.m.c.'s are small and no cell walls are laid down until after meiosis. 
(ii) L. autumnalis

(figs. I-3; plate I (e); table 7)

Meiosis is similar and regular in all plants except those with a paracentric inversion or an interchange. Chiasmata are distally
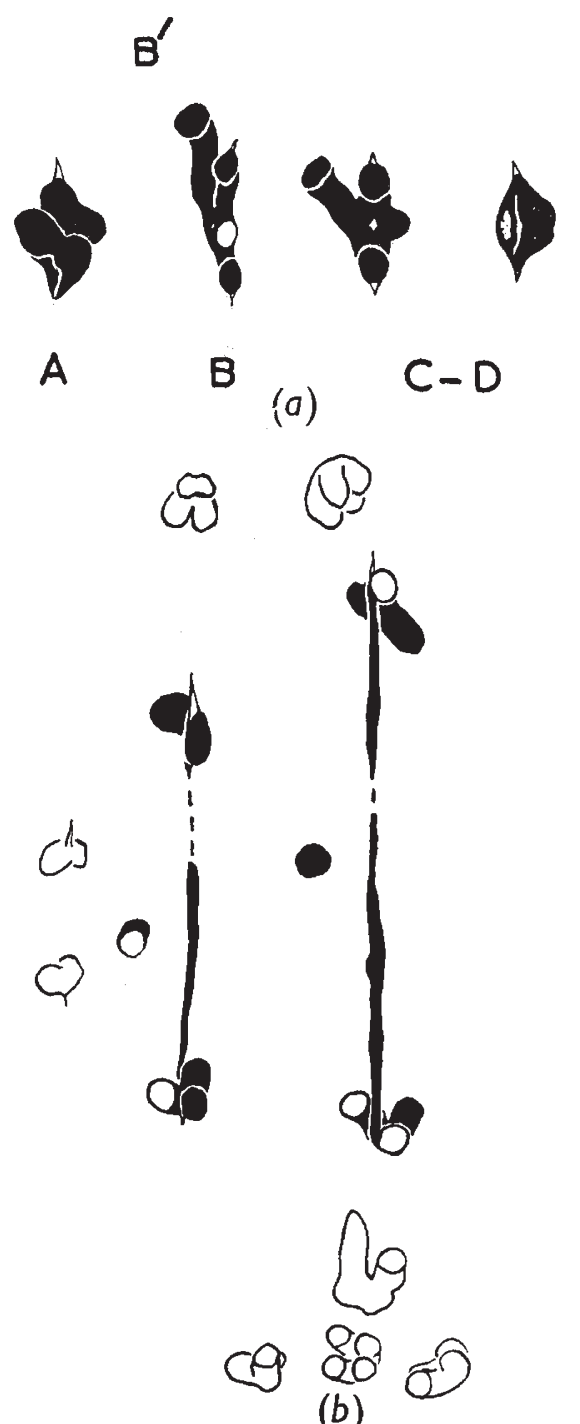

Fig. 6. - L. taraxacoides: aneuploid $(2 \mathrm{n}=\mathrm{II})$ at $\mathrm{MI}(a)$ and $\mathrm{AI}(b)$. In $(b)$ the $\mathrm{A}$ chr. bridge and fragment is at right.

localised and no bivalent has more than two. When chromosomes A and $\mathrm{B}$ are differentiated by the interchange between chromosomes $\mathrm{A}$ and $\mathrm{E}$, the chiasma frequency of the two pairing segments of chromosome $\mathrm{A}$ about equals that of those of chromosome $\mathbf{B}$.

Chiasma localisation is genotypically controlled and not due simply 
to chromosome shape. This is shown by the variant forms of chromosomes $\mathrm{C}, \mathrm{E}$ and $\mathrm{F}$, in which the normal pairing segments are maintained even in the homozygotes seen, despite the relative shortening of the arms bearing such segments and lengthening of arms with non-pairing segments. This cannot be seen directly in $\mathrm{C}_{2}$ homozygotes because of confusion between chromosomes $\mathrm{C}_{2}$, A and $\mathrm{B}$, but it seems likely because all ring bivalents in such homozygotes can be accounted for by chromosomes $A$ and $B$. In all normal and variant plants, most p.m.c.'s have one ring bivalent, but some have nought or two and in all

TABLE 7

L. autumnalis: chiasma frequencies in the six bivalents of eight different plants (20 p.m.c.'s each)

\begin{tabular}{|c|c|c|}
\hline \multirow{2}{*}{$\begin{array}{c}\text { Plant } \\
\text { karyotype }\end{array}$} & \multicolumn{2}{|c|}{ Chiasmata per bivalent } \\
\hline & $A-B$ & C.F \\
\hline Normal & $I \cdot 55$ & $\mathrm{I} \cdot \mathrm{OO}$ \\
\hline $\mathrm{FI}_{\mathrm{I}} 2$ & $1 \cdot 5^{8}$ & I $\cdot 00$ \\
\hline FI.3 & I 43 & $\mathrm{I} \cdot \mathrm{OO}$ \\
\hline$F_{2.2}$ & I. 63 & I $\cdot 00$ \\
\hline $\mathrm{F}_{3} \cdot 3$ & $1 \cdot 60$ & I $\cdot 00$ \\
\hline $\mathrm{G}_{\mathrm{I} .2} \mathrm{~F}_{\mathrm{I} .2}$ & I 55 & I $\cdot 00$ \\
\hline $\mathrm{C}_{2.2}$ & $1 \cdot 4^{8}$ & I 'oo \\
\hline $\mathrm{E}_{\mathrm{I} \cdot 3}$ & I $\cdot 55$ & $\mathrm{I} \cdot \mathrm{OO}$ \\
\hline
\end{tabular}

types but $\mathrm{C}_{2}$ homozygotes, these ring bivalents can be seen to be formed by chromosomes $\mathrm{A}$ and $\mathrm{B}$. No unequal bivalents were seen in the $\mathrm{C}_{2.2}$ plant which was examined at diakinesis, the best stage for distinguishing metacentrics from acrocentrics. The plant is therefore homozygous for one variant metacentric type and not heterozygous for two types.

In paracentric inversion plants, meiosis is normal except for the formation of inversion bridges and fragments.

In the interchange heterozygote, meiosis is normal except that the interchange complex forms either two asymmetric bivalents or a chain of four at MI and may show irregular distribution of its members at later stages. The expected association of three with chromosome $\mathrm{Ai}$ univalent has not been found for certain. The unlikely association of three with chromosome $\mathrm{E}$ univalent, corresponding to failure of chiasma-formation between the $\mathrm{E}$ chromosomes in a normal plant, does not occur.

\section{(iii) L. taraxacoides and L. hispidus \\ (figs. 5-7; plate I (a); tables 8, 9)}

In both species, chiasmata in all chromosomes occur at random along either arm except very near the centromere. All variant plants studied, apart from triploids and aneuploids, closely resemble normal plants at meiosis. Paracentric inversions cause no irregularity besides 
TABLE 8

L. taraxacoides: chiasma frequencies in normal, variant and backcross plants (20 p.m.c.'s each). The upper figures for each plant give the total numbers of chiasmata, the lower figures give the numbers in the short arms

\begin{tabular}{|c|c|c|c|}
\hline \multirow{2}{*}{$\begin{array}{l}\text { Plant } \\
\text { type }\end{array}$} & \multicolumn{3}{|c|}{ Chiasmata per bivalent } \\
\hline & A & B & C, D \\
\hline \multirow[t]{2}{*}{ Normal } & $\mathrm{I} \cdot 75$ & $1 \cdot 10$ & I $\cdot 03$ \\
\hline & 0.50 & 0.25 & $0 \cdot I_{5}$ \\
\hline \multirow[t]{2}{*}{ Normal } & $1 \cdot 40$ & $\mathrm{I} \cdot \mathrm{IO}$ & I $\cdot 00$ \\
\hline & $\begin{array}{l}0.85 \\
1 \cdot 55\end{array}$ & $\begin{array}{l}0.45 \\
I \cdot 15\end{array}$ & $\begin{array}{l}0.28 \\
.08\end{array}$ \\
\hline $\mathbf{B B}^{\prime}$ & 0.35 & $0 \cdot 15$ & $0 \cdot 28$ \\
\hline \multirow[t]{2}{*}{$\mathrm{BB}^{\prime}$} & $1 \cdot 15$ & $\mathrm{I} \cdot 05$ & I $\cdot 00$ \\
\hline & 0.20 & 0.05 & 0.23 \\
\hline \multirow[t]{2}{*}{$\mathrm{BB}^{\prime}$} & $1 \cdot 30$ & $\mathrm{I} \cdot 00$ & $\mathrm{I} \cdot \mathrm{OO}$ \\
\hline & $0 \cdot 15$ & $0 \cdot 00$ & $0 \cdot 13$ \\
\hline $\begin{array}{l}\text { Backcross clone } 15^{*} \\
\left(F_{I} \times L \text {. taraxacoides }\right)\end{array}$ & $\begin{array}{l}I \cdot 30 \\
0 \cdot 15\end{array}$ & \multicolumn{2}{|c|}{$\begin{array}{l}1 \cdot 15 \\
0 \cdot 31\end{array}$} \\
\hline
\end{tabular}

* Bivalent $A$ is that on the left in fig. $10(b)$.

\section{TABLE 9}

L. hispidus: chiasma frequencies in normal, variant and backcross plants (20 p.m.c.'s each). Arranged as in Table 8. Short arms in chromosome $C$ are assumed to form chiasmata only in ring bivalents

\begin{tabular}{|c|c|c|c|c|c|c|}
\hline \multirow{2}{*}{$\begin{array}{c}\text { Plant } \\
\text { type }\end{array}$} & \multicolumn{6}{|c|}{ Chiasmata per bivalent } \\
\hline & A & B & G & $\mathrm{D}$ & $\mathbf{E}, \mathbf{F}$ & G \\
\hline Normal & \multicolumn{2}{|c|}{$\begin{array}{l}1 \cdot 75 \\
0 \cdot 05\end{array}$} & $\begin{array}{l}1 \cdot 25 \\
0 \cdot 25\end{array}$ & $\begin{array}{l}1 \cdot 25 \\
0 \cdot 05\end{array}$ & \multicolumn{2}{|c|}{$\begin{array}{l}I \cdot 02 \\
0 \cdot 05\end{array}$} \\
\hline Normal & \multicolumn{2}{|c|}{$\begin{array}{l}1 \cdot 53 \\
0 \cdot 08\end{array}$} & $\begin{array}{l}1 \cdot 30 \\
0 \cdot 30\end{array}$ & $\begin{array}{l}I \cdot I 5 \\
0 \cdot 00\end{array}$ & \multicolumn{2}{|c|}{$\begin{array}{l}I \cdot 02 \\
0 \cdot 05\end{array}$} \\
\hline AI.2 & $\begin{array}{l}0 \cdot 05 \\
0.05\end{array}$ & $\begin{array}{l}I \cdot 55 \\
0 \cdot 30\end{array}$ & $\begin{array}{l}1 \cdot 65 \\
0.65\end{array}$ & $\begin{array}{l}I \cdot 25 \\
0 \cdot 00\end{array}$ & \multicolumn{2}{|c|}{$\begin{array}{l}I \cdot 00 \\
0 \cdot 02\end{array}$} \\
\hline $\mathrm{C} 1.2$ & \multicolumn{2}{|c|}{$\begin{array}{l}1 \cdot 38 \\
0 \cdot 05\end{array}$} & $\begin{array}{l}I \cdot I 5 \\
\text { O-I } 5\end{array}$ & $\begin{array}{l}I \cdot I 5 \\
0 \cdot 00\end{array}$ & \multicolumn{2}{|c|}{$\begin{array}{l}I \cdot 00 \\
0 \cdot 00\end{array}$} \\
\hline $\mathrm{CI}_{3}$ - Gi.2 & \multicolumn{2}{|c|}{$\begin{array}{l}\mathrm{I} \cdot 75 \\
\mathrm{O} \cdot \mathrm{I} 5\end{array}$} & $\begin{array}{l}I \cdot 00 \\
0 \cdot 00\end{array}$ & $\begin{array}{l}1 \cdot 20 \\
0 \cdot 00\end{array}$ & $\begin{array}{l}I \cdot 02 \\
0 \cdot 00\end{array}$ & $\begin{array}{l}1 \cdot 00 \\
0 \cdot 00\end{array}$ \\
\hline GI.2 & \multicolumn{2}{|c|}{$\begin{array}{l}\text { I } 68 \\
\text { o.00 }\end{array}$} & $\begin{array}{l}I \cdot 20 \\
0 \cdot 20\end{array}$ & $\begin{array}{l}I \cdot 20 \\
0 \cdot 00\end{array}$ & $\begin{array}{l}\mathrm{I} \cdot 00 \\
0 \cdot 05\end{array}$ & $\begin{array}{l}I \cdot 00 \\
0 \cdot 00\end{array}$ \\
\hline $\begin{array}{l}\text { Backcross clone } 2 \\
\left(\text { L. hispidus } \times \mathrm{F}_{\mathrm{I}}\right)\end{array}$ & \multicolumn{2}{|c|}{$\begin{array}{l}I \cdot 23 \\
0 \cdot 00\end{array}$} & $\begin{array}{l}I \cdot 00 \\
0 \cdot 00\end{array}$ & $\begin{array}{l}I \cdot I 5 \\
0 \cdot 00\end{array}$ & $\begin{array}{l}I \cdot 25 \\
0 \cdot 00\end{array}$ & $\begin{array}{l}0 \cdot 00 \\
0 \cdot 00\end{array}$ \\
\hline
\end{tabular}


the formation of anaphase bridges and fragments. All variant types, but not individuals, have been studied at meiosis except triploid, aneuploid, Fr.2 and Gr.3 plants of $L$. hispidus. Irregularities are confined to variant chromosomes and their partners.

In $L$. taraxacoides, Chromosome $\mathrm{B}^{\prime}$ behaves regularly and forms chiasmata along all its length except in the proximal part of the short arm, where chiasmata never occur. It also behaves as regularly as Chromosome B when in triploids and aneuploids.

Triploids and their aneuploid progeny show the meiotic behaviour usual for these types of plant. Exactly four associations (bivalents or trivalents), all seemingly legitimate, are formed at MI. Misdivision of univalents is fairly common and may occur at either anaphase.

In the interchange plant, the complex may form associations of four or of three with one univalent or it may form two unequal bivalents.

In L. hispidus, chromosome $\mathrm{A}_{2}$ is usually left univalent with its complete homologue at MI. The two univalents behave as is usual in such cases. In one p.m.c., the long arm of chromosome $\mathrm{A}_{2}$ formed a chiasma with the short arm of chromosome AI. Chromosomes $\mathrm{C}_{2}$ and $\mathrm{C}_{3}$ usually form a chiasma with chromosome $\mathrm{C}_{\mathrm{I}}$ in the complete arm. They behave regularly except for rare failure of chiasma formation. Ghromosome $\mathrm{C}_{2}$ occasionally forms a chiasma with chromosome $\mathrm{C}_{\mathrm{I}}$ in both arms at once, but chromosome $\mathrm{C}_{3}$ never does this.

Chromosome $\mathrm{G}_{2}$ behaves regularly.

The interchange complex in the $\mathrm{Cr}_{\mathrm{r}}$ G G.2 plant usually forms two bivalents indistinguishable from normal $\mathrm{A}$ and $\mathrm{D}$ bivalents. The ring of four in fig. $7(c)$ is rare and no other type of irregular association has been seen.

\section{FERTILITY IN VARIANTS OF THE THREE SPECIES}

Except for the interchange heterozygote, all $L$. autumnalis variants are fully fertile, like normal plants, on open pollination. Evidently chiasmata are absent from the proximal regions affected by centric shift, and the anaphase bridges and fragments in the two apparent paracentric inversion plants are very rare. The interchange plant is semi-sterile on open pollination.

In $L$. taraxacoides, chromosome $\mathrm{B}^{\prime}$ has no effect on the fertility of open-pollinated diploids or triploids. Triploids ripen about 20 per cent. of seed when pollinated by diploids and their pollen likewise causes about 20 per cent. seed-ripening in diploids.

The fertility of other L. taraxacoides variants is not known.

The fertilities of $L$. hispidus variants studied are given in table 10. Except in the case of the Ar.2 plant, which was pollinated experimentally only by the Gr.2 plant, they are expressed as the percentage of seeds ripened by the female head in crosses with normal plants. Two normal plants crossed together usually give fertilities varying between 70 and 100 per cent. and so the fertilities in table Io may not be maximal. 
A
B
C
D
E $F \quad G$
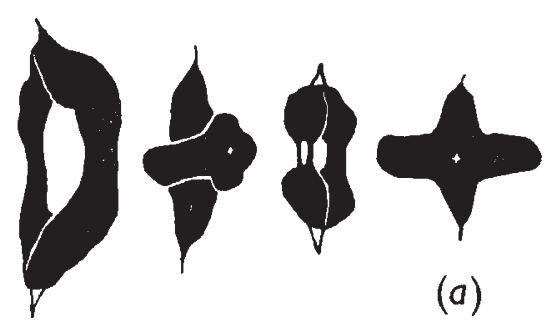

(a)

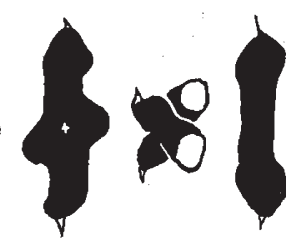

A 2

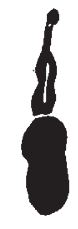

Al

III

$2 I$

(b)
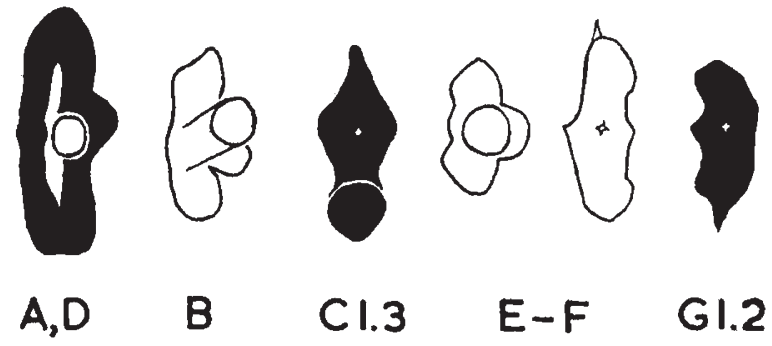

B

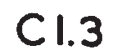

$E-F$

GI.2

(c)

FIG. 7.-L. hispidus: MI in normal $2 x(a)$, AI.2 pair (b), GI.3 GI.2 plant (c). The A-D interchange ring at left in $(c)$ is rare and normal $\mathrm{A}$ and $\mathrm{D}$ bivalents are usually formed in its place.

TABLE Io

L. hispidus: fertility of variants in crosses with normal plants

\begin{tabular}{|l|c|c|}
\hline \multirow{2}{*}{ Type } & \multicolumn{2}{|c|}{ Fertility per cent. as } \\
\cline { 2 - 3 } & female & male \\
\hline & & \\
A I .2 & $21^{*}$ & $\ldots$ \\
$\mathrm{CI}_{\mathrm{I} .3} \mathrm{G}_{1.2}$ & $5^{2}$ & 54 \\
$\mathrm{GI}_{\mathrm{I} .2}$ & 34 & 39 \\
& 80 & 70 \\
\hline
\end{tabular}

* In the cross, AI.2 $\times$ GI.2; an open pollination, probably by normal plants, gave 19 per cent. 
The Gr.2 plant is as fertile as a normal plant, in spite of being heterozygous for inversions in chromosomes $\mathrm{A}$ and $\mathrm{G}$.

Among deficiency plants, fertility probably decreases as the size of the deficiency increases.

\section{CROSSES INVOLVING VARIANTS IN L. TARAXACOIDES AND L. HISPIDUS}

(tables I I, I 2)

(i) Inheritance of variant chromosomes

In $L$. taraxacoides, chromosome $\mathrm{B}^{\prime}$ is transmissible through both pollen and egg in both diploids and triploids. The inversion form of chromosome $\mathrm{A}$ in the triploid can also be inherited through both pollen and egg.

TABLE II

L. hispidus: frequencies of different karyotypes in samples of progeny from crosses

\begin{tabular}{|c|c|c|c|c|c|c|c|c|}
\hline \multirow{3}{*}{ Cross } & \multicolumn{8}{|c|}{ No. of progeny of type } \\
\hline & \multicolumn{6}{|c|}{$2 n=\mathrm{I} 4$} & \multicolumn{2}{|c|}{$2 n=\mathrm{I} 5$} \\
\hline & Normal & $\mathrm{C}_{\mathrm{I} .2}$ & $\mathrm{C}_{1} \cdot 3$ & $\mathrm{CI}_{\mathrm{I} \cdot 3} \mathrm{GI}_{\mathrm{I} 2}$ & $\mathrm{G}_{\mathrm{I} .2}$ & Gi.3 & Al.1.2 & $\underset{\mathrm{G}_{\mathrm{I} .2}}{\mathrm{~A}_{\text {I.I }}}$ \\
\hline $\mathrm{AI} .2 \times \mathrm{C}_{1.2} *$ & 3 & I & $\ldots$ & $\ldots$ & $\ldots$ & I & 3 & $\ldots$ \\
\hline Gi.3 Gi.2 $\times$ normal & 6 & $\ldots$ & I & $\ldots$ & I & $\ldots$ & $\ldots$ & I \\
\hline Normal $\times \mathrm{C}_{1.3} \mathrm{G}_{1.2}$ & 4 & $\ldots$ & $\ldots$ & $\ldots$ & 4 & $\ldots$ & $\ldots$ & $\ldots$ \\
\hline GI.2 $\times$ normal & I & $\ldots$ & ... & $\mathrm{I} \dagger$ & $\cdots$ & $\ldots$ & $\ldots$ & $\ldots$ \\
\hline Normal $\times$ GI.2 & $\ldots$ & $\ldots$ & $\ldots$ & $\ldots$ & I & $\ldots$ & $\ldots$ & $\cdots$ \\
\hline
\end{tabular}

* As pollination bags were not used in this cross, it is possible but not likely, that variant chromosomes came from foreign pollen.

$\dagger$ Interchange heterozygote (fig, $7(c)$ ).

TABLE I 2

L. taraxacoides: aggregate frequencies in $B B B$ and $B B B^{\prime}$ triploids of different gametic chromosome numbers as deduced from crosses with diploids

\begin{tabular}{|l|c|c|c|c|c|}
\hline \multirow{2}{*}{ Gamete } & \multicolumn{5}{|c|}{ Gametic chromosome No. } \\
\cline { 2 - 5 } & 4 & 5 & 6 & 7 & 8 \\
\hline $\begin{array}{l}\text { Female } \\
\text { Male }\end{array}$ & 2 & 3 & 3 & 5 & 6 \\
\hline
\end{tabular}

In L. hispidus, chromosome $\mathrm{G}_{2}$ comes through both pollen and egg, but the deficiency chromosomes seem less viable. Chromosome $\mathrm{C}_{2}$, with the smallest deficiency comes through the pollen. No pollination bags were used in this particular cross, but the result is probably genuine. This chromosome was not tested in the egg. 
Chromosome $\mathrm{C}_{3}$, with a larger deficiency, is transmissible through the egg, but has not yet survived in pollen. Chromosome A2, with its enormous deficiency is transmissible through the egg only as a supernumerary. It has not been tested in pollen.

\section{(ii) New chromosome numbers and types}

In $L$. taraxacoides, the progeny of crosses between triploids and diploids show all chromosome numbers from 8 to 12 , inclusive. Functional eggs from triploids may have any number from 4 to 8 , inclusive. Functional male gametes are usually haploid, or rarely diploid, but seem never to be aneuploid. Aneuploid pollen grains are probably formed by triploids, but do not function, for at least 60 of the 64 potential pollen grains from i 6 p.m.c.'s seen at AI, MII and AII would have been aneuploid. In progeny, chromosome $\mathrm{A}$ is either trisomic or disomic and meiosis, when seen, shows this to hold also for chromosomes B-D.

In L. hispidus, the AI.2 and $\mathrm{G}_{\mathrm{I} .3} \mathrm{GI}_{\mathrm{I} .2}$ plants produced a trisomic type each, as females. This is predictable from their disturbed meiosis. Non-disjunction of the univalent $\mathrm{A}_{1}$ and $\mathrm{A}_{2}$ Chromosomes in the first plant and of the members of the A-D interchange ring in the second one would give rise to the AI.I.2 and AI.I.I trisomics, respectively, found in the progenies.

Two new deficiency chromosomes, $\mathrm{C}_{3}$ and $\mathrm{G}_{3}$, arose in crosses. The interchange in the $\mathrm{G}_{\mathrm{I} .3} \mathrm{G}_{\mathrm{I} .2}$ plant may also have arisen at the same time as the $\mathrm{C}_{3}$ Chromosome (see "Spontaneous Chromosome Mutation").

\section{THE F1 HYBRID BETWEEN L. TARAXACOIDES AND L. HISPIDUS \\ (i) Phenotype}

The $F_{I}$ hybrid is easy to obtain from seeds of either species parent and is fully viable. Both wild and artificial hybrids are intermediate between the two species in size, number of florets per head and all other characters except that the marginal fruits (cypselas) nearly always resemble those of $L$. taraxacoides. Pappus-development on marginal fruits often varies from head to head on the same plant. Only two out of nineteen artificial hybrids seen closely resemble L. hispidus in having a fully-developed pappus on these fruits. Fifteen have the pappus reduced to a crown of scales and two have mainly intermediate pappus-development on the marginal fruits. Scapes and heads may be glabrous, hispid or intermediate in different individuals.

\section{(ii) Mitotic chromosomes}

The hybrid complement contains the expected eleven chromosomes. A given chromosome type is no different in size or any other character in the hybrid cell from the same type in the pure species. L. taraxacoides chromosomes $\mathrm{B}, \mathrm{C}$ and $\mathrm{D}$ are the smallest in the hybrid cell and are 
easily distinguishable from the others. L. taraxacoides chromosome A can be distinguished from L. hispidus chromosomes $\mathrm{E}, \mathrm{F}$ and $\mathrm{G}$ in good preparations. When chromosome $\mathrm{B}^{\prime}$ is used as a further marker in an artificial hybrid, the difference in size between the complements of the two species is placed beyond doubt. Elliot (1950), in her account of the $\mathrm{F}_{\mathrm{I}}$ karyotype seems to have over-estimated the relative size of the $L$. taraxacoides complement and to have overlooked some satellites.

\section{(iii) Meiosis}

Prophase I. The pachytene chromosomes are too tangled to be distinguished individually. About one third of their total length is paired, as though the whole $L$. taraxacoides complement were paired with $L$. hispidus chromosomes (plate I $(b)$ ). From diplotene to diakinesis, the chromosomes are distributed at random within the nucleus, often attenuated and sticking together haphazardly. Observation is difficult, but a small amount of chromosome breakage seems to occur before first anaphase in a few p.m.c.'s.

Metaphase I. Chiasma frequencies are very low. They vary both within and between plants. The mean number of chiasmata per p.m.c. in 59 p.m.c.'s in 3 fixations of 2 different plants is o.322. At MI, the chromosomes are usually all univalent, but non-chiasmate associations are frequent (fig. $8(a)$ ). Comparison between aceto-carmine and acetic alcohol fixations of the same flower head shows that acetic alcohol fixation causes chromosomes which are merely touching or close to one another to swell and fuse into pseudo-chiasmate associations of two or more (fig. $8(b)$, plate $\mathrm{I}(c),(d))$. This is especially deceptive when several such associations are orientated parallel to one another like bivalents round a metaphase plate. The chiasma frequency was estimated therefore only from cells fixed in aceto-carmine. No chiasmate associations of more than three and no cells with more than four chiasmata have been seen. Acrocentrics form chiasmata only in the long arm. Because of the small size and highly contracted and usually crowded state of the chromosomes, the different types are hard to identify at MI, but there seems to be little or no intragenomic chiasmaformation.

One slide from an acetic alcohol fixation seems to show a physiological difference between chiasmate and achiasmate p.m.c.'s (fig. $8(b)$ ). The chromosomes in the two p.m.c.'s with two or three definite bivalents show coiling like those in aceto-carmine fixations, whereas the rest of the p.m.c.'s on this slide, which are probably achiasmate, contain sticky chromosomes with the smooth outlines usual in acetic alcohol preparations.

Anaphase I. At AI, most chromosomes migrate to a pole. The rest either divide equationally or misdivide (figs. $8(c),(d)$ and $9(b)$ ). Each pole usually receives 4-7 chromosomes with marker types distributed at random.

AI bridges and fragments are fairly frequent. The mean number 
per p.m.c. of anaphase chromatid bridges in $4^{8}$ p.m.c.'s from the slides used to estimate chiasma frequencies is 0.306 , including 3 chromosome bridges scored as a total of 6 chromatid bridges. Sometimes a fragment occurs without a bridge. The occurrence of bridges and

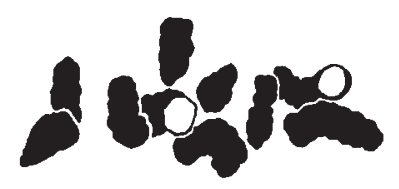

(a).

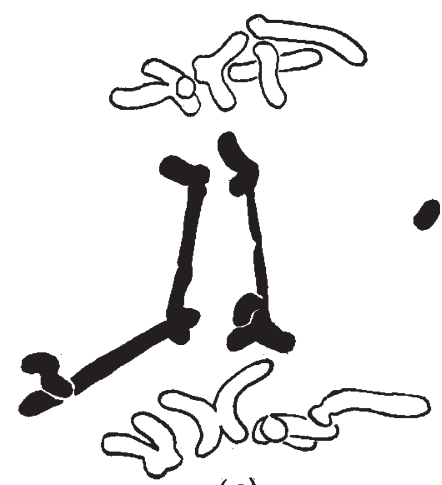

(c)

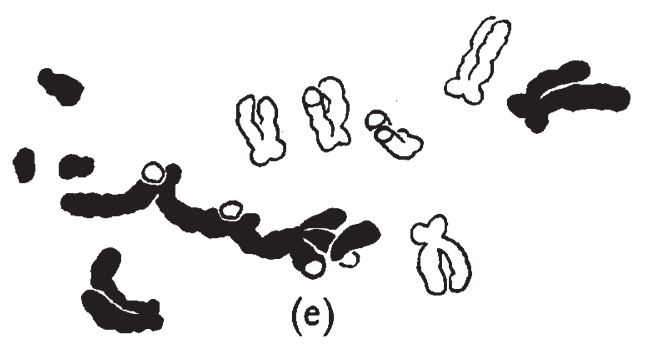

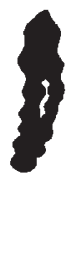

(b)
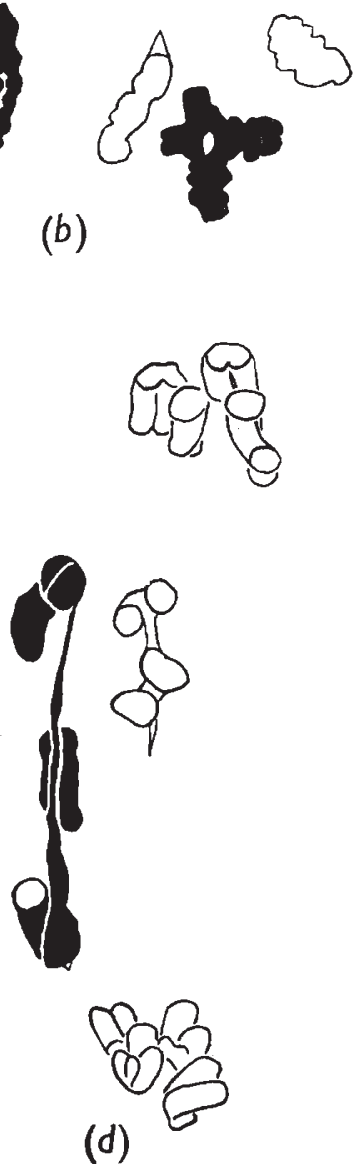

(d)

FIg. 8.-L. taraxacoides-L. hispidus FI hybrid: (a) II I at MI. (b) 3 II + I pseudo-bivalent (ps) +3 I. (c)-(e) AI. In $(d)$ L. hispidus A and B chrs. form the bridge and fragment. In $(e) 2$ chrs. drawn solid (like those forming the bridges) have long arm chromatids. of unequal length and are probably the products of a reciprocal unequal exchange. Aceto-carmine fixation in $(a)$ and $(e)$.

fragments shows certain regularities, and their mode of formation is treated in the main discussion.

(I) Most bridges are chromatid bridges. Chromosome bridges (fig. $9(a)$ ) are rare.

(2) In most plants, not more than one bridge occurs in a cell. In the clone with the highest frequency of bridges, however, four of the six p.m.c.'s with bridges have two chromatid bridges each (fig. $8(c)$ ) and $a$ fifth has three (fig. $8(e)$ ). In this clone, the same four 
chromosome types may be involved in all five p.m.c.'s with more than one bridge.

(3) In acrocentrics, bridges are nearly always in the long arms.

(4) All bridges but one (fig. $8(d)$ ) can be interpreted as intergenomic and most can be interpreted only thus.

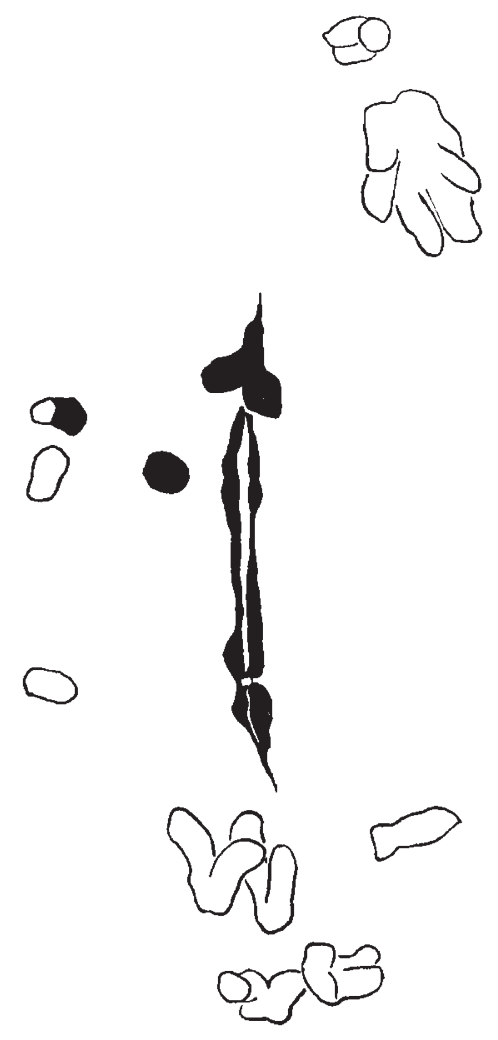

(a)

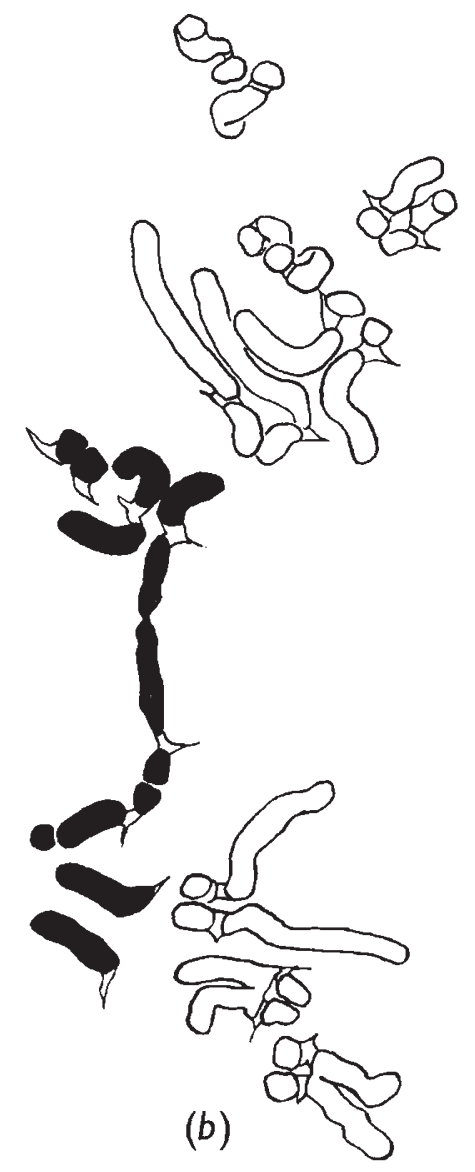

(b)

FIG. 9.-L. taraxacoides-L. hispidus F I hybrid: (a) double bridge and fragments (solid) at AI. The 2 small bodies at left centre may also be fragments. (b) AI bridge and fragment and a chromosome which misdivided at AI are drawn (solid) at AII.

(5) Each bridge is usually accompanied by one fragment. With occasional exceptions, the fragments associated with bridges involving L. hispidus chromosomes A or B are large and those associated with other bridges are medium-sized to small.

Telophase $I$ and second division. After AI, various irregularities follow. These include lagging and loss of chromosomes and chromatids and the formation of micronuclei. The occurrence of occasional dyads in with the tetrads shows that restitution nuclei may be formed. These presumably give the unreduced gametes which are detected in backcrosses. 


\section{(iv) Fertility and gametes}

In most backcrosses, FI hybrids gave no good seeds at all; but successful backcrosses of very low yield were eventually obtained both ways with each species (table I3).

The karyotypes of hybrid gametes are calculable from the karyotypes of backcrosses when the species parents are known. In backcrosses, three kinds of chromosome variation are observed. They stem from the presence of new chromosome types, from new combinations of apparently normal types and from various combinations of new and old types. Much unobservable variation must also occur, for one cannot deduce genotype from karyotype nor tell the homologies of unpaired chromosomes which often occur at meiosis in backcrosses.

TABLE I 3

Yields in attempted backcrosses. Several different plants of each type were used in the 50 crosses.

\begin{tabular}{|c|c|c|c|c|c|}
\hline \multirow{2}{*}{ Cross } & \multirow{2}{*}{ No. of heads } & \multicolumn{2}{|c|}{ Total No. of seeds } & \multicolumn{2}{|c|}{$\begin{array}{l}\text { Highest No. of seeds from } \\
\text { one head }\end{array}$} \\
\hline & & Set & Germinated & Set & Germinated \\
\hline $\begin{array}{l}\mathrm{T} \times \mathrm{Fl} \\
\mathrm{Fl} \times \mathrm{T} \\
\mathrm{H} \times \mathrm{Fl} \\
\mathrm{Fl} \times \mathrm{H}\end{array}$ & $\begin{array}{l}\text { I0 } \\
\text { I5 } \\
\text { II } \\
\text { I } 4\end{array}$ & $\begin{array}{r}13 \\
7 \\
27 \\
8\end{array}$ & $\begin{array}{l}2^{*} \\
4 \\
7 \\
5\end{array}$ & $\begin{array}{l}1 \\
2 \\
7 \\
2\end{array}$ & $\begin{array}{l}1 \\
2 \\
7 \dagger \\
2\end{array}$ \\
\hline
\end{tabular}

* One due to selfing.

$\dagger$ Not more than one due to selfing.

A mitotic classification of I9 backcross karyotypes, which is broadly supported by meiotic behaviour where this is known (in 8 plants), yields the following information.

Most chromosomes in hybrid gametes are of normal parental type. Marker chromosomes occur independently of one another. Seventeen different karyotypes occur in the nineteen gametes studied.

Twelve gametes have detectable rearrangements in the chromosomes. New chromosome types detectable at mitosis include (I) some which are like $L$. hispidus A chromosomes, but have satellites or median centromeres, (2) L. hispidus C, D, E, F and $\mathrm{G}$ chromosomes in addition to those contributed as such by the parents, and (3) centric fragments. At meiosis, interchanges and translocations may be revealed (fig. I I).

Some new chromosome types such as extra $L$. hispidus $\mathrm{C}$ and interchanged $L$. hispidus $\mathrm{A}$ and $\mathrm{D}$ chromosomes cannot have been formed by known chiasmate associations and are probably the result of random chromosome breakage and reunion.

In backcrosses with both species, seven is much the commonest chromosome number in successful hybrid gametes, male and female 
(table I4). As in triploid L. taraxacoides, aneuploid pollen is eliminated, but aneuploid eggs are not.

Some, but not all, gametes with seven chromosomes have karyotypes much like that of a normal $L$. hispidus gamete.

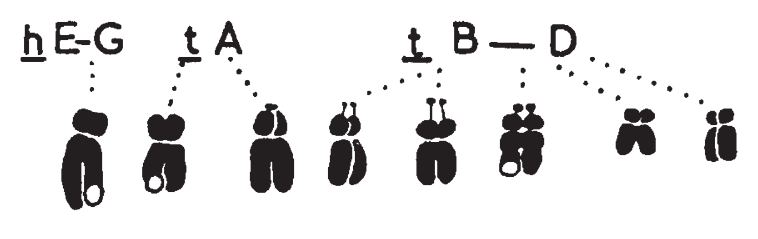

(a)

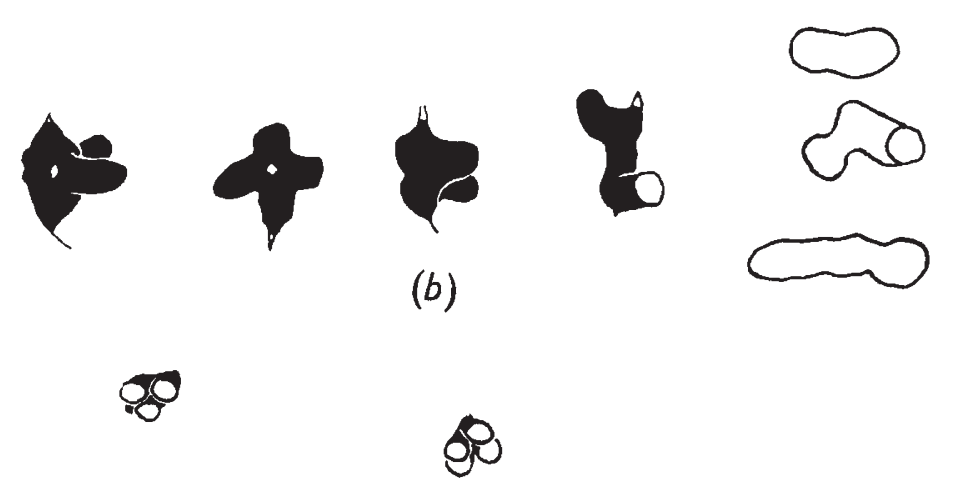

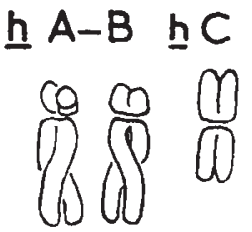
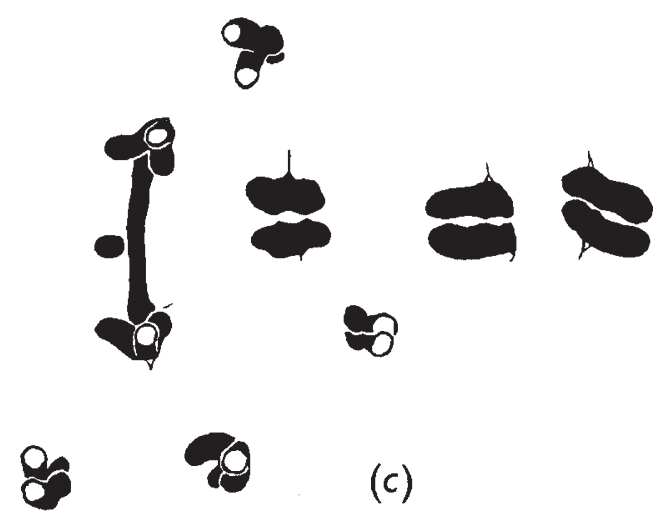

(c)

FIG. I $0-B$-Backcrosses between $L$. taraxacoides and the L. taraxacoides-L. hispidus F I hybrids: $(a),(b)$ clone ${ }_{15},(c)$ clone 13. (a) Mitosis. (b) 4 II (2 at left unequal) +3 I (L. hispidus chrs.). (c) AI with L. taraxacoides A chrs. forming bridge and fragment, 3 L. taraxacoides $\frac{1}{2}$-bivalents moving to each pole and 3 L. hispidus univalents dividing on the plate.

\section{FIRST-GENERATION BACKCROSSES}

\section{(i) Phenotype}

Most backcrosses resemble their species parent in general size and appearance, but nearly all show signs of the other species as well. Many are stunted, deformed or inviable as seedlings and a few are 
stunted or deformed as adults. All of 6 with L. taraxacoides as species parent have L. taraxacoides-type marginal fruits and so do about half of 12 backcrossed with L. hispidus.

The backcross found in the wild differs from typical L. hispidus plants from that population only in that most of its marginal fruits are of the L. taraxacoides type. It is closely similar to many experimental first-generation backcrosses.

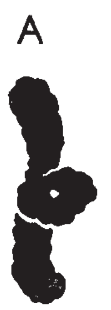

A,D

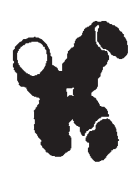

B

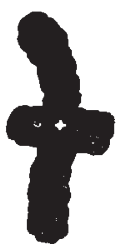

the
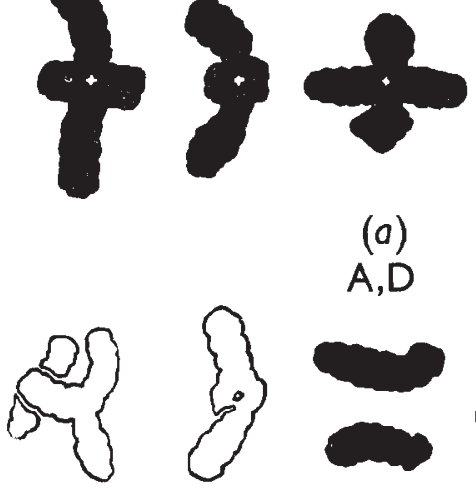

(a)

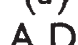

D

A,D

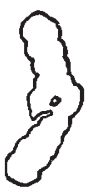

$E$
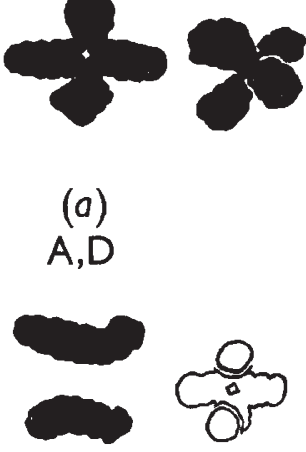

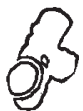

F $\quad G$
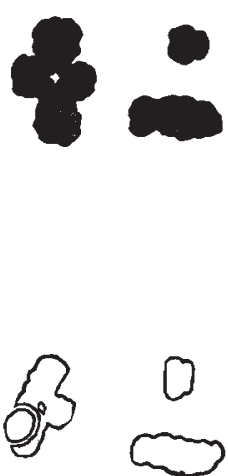

(b)

FIG. II.-Backcross between $L$. hispidus and the $L$. taraxacoides-L. hispidus FI hybrid: MI in clone 2. (a) Usual $6 \mathrm{II}+2 \mathrm{I}$. (b) A-D interchange revealed by unequal II +2 unequal $\mathbf{I}$.

\section{(ii) Mitotic chromosomes}

All chromosome numbers from eleven to eighteen, inclusive, except seventeen, have been found in backcrosses. Unlike the wild backcross, which is probably not a first-generation backcross, no backcross was karyotypically identical with either species, though a few were closely similar (fig. I I). The types of variation found are discussed under "Fertility and gametes" in the section on the FI hybrid.

\section{(iii) Meiosis}

(figs. Io, II; tables 8, 9)

Eight first-generation backcrosses and one second-generation backcross have been seen at meiosis. In those which seem to have nearly exact diploid complements of one species and few chromosomes of the other, meiosis is chiasmate (fig. II). Small abnormalities due to interchange or inversion hybridity occur and a few p.m.c.'s may show occasional failure of chiasma-formation in one or two pairs. Otherwise, meiosis in these plants resembles that of the species whose 
chromosomes predominate. The chromosomes of the other species probably never form chiasmata (fig. Io $(b)$ ).

In plants where the karyotype does not closely resemble that of either species, meiosis is nearly achiasmate and like that in the $\mathrm{F}_{\mathrm{I}}$ hybrid.

TABLE I4

L. taraxacoides-L. hispidus $F_{1}$ hybrid: frequencies of different gametic chromosome numbers as deduced from 27 backcrosses

\begin{tabular}{|c|c|c|c|c|c|c|c|}
\hline \multirow{3}{*}{ Species parent } & \multicolumn{7}{|c|}{ Gametic chromosome No. } \\
\hline & \multicolumn{5}{|c|}{ Female } & \multicolumn{2}{|c|}{ Male } \\
\hline & 6 & 7 & 8 & 9 & I I & 7 & II \\
\hline L. taraxacoides & o & 3 & I & I & o & I & o \\
\hline L. hispidus & I & 9 & 2 & I & I & 5 & 2 \\
\hline
\end{tabular}

(iv) Fertility

Probably all backcrosses are at least as fertile as Fi hybrids. After open pollination, most are more fertile than this and some are as fertile as either species. In general, plants with meiosis giving rise to gametes resembling those of the pure species are the most fertile.

Fertility is likely to increase with repeated backcrossing with the same species. Thus one backcross (F I $\times$ L. hispidus) which has achiasmate meiosis and nearly zero fertility, gave rise, when pollinated with L. hispidus, to plants which are fairly fertile and have, in at least one case, chiasmate meiosis. The wild backcross is fully fertile when openpollinated.

\section{DIRECT EFFECTS OF CHROMOSOME VARIATION ON PHENOTYPE}

Only in the following cases does chromosome variation seem to be correlated with phenotypic abnormality. Comparisons in this section are between plants grown in similar, but not identical, conditions.

Most aneuploids in L. taraxacoides are smaller and more prone to fasciation than their diploid sibs. They also die more quickly if accidentally exposed to drought, overheating or pests in the greenhouse.

All triploids from crosses in L. taraxacoides are slightly larger than their diploid sibs, but the wild triploids in this species and in L. hispidus were not noticeably robust in the field. The wild normal triploid in L. taraxacoides was more robust in cultivation than diploids and a $\mathrm{BBB}^{\prime}$ triploid from the same population. The two wild $\mathrm{BBB}^{\prime}$ triploids are no bigger than diploids from their populations. 
The Ar.2 plant in L. hispidus is slightly stunted compared with its sibs.

The F I hybrid between L. taraxacoides and L. hispidus is intermediate in phenotype between the parents.

In backcrosses, the situation is complex and unanalysable beyond the observation that backcrosses tend to resemble their species parents in morphology and that this tendency is less among those in which the karyotype is less like that of the species parent.

\section{SPONTANEOUS CHROMOSOME MUTATION}

Spontaneous interchanges and gains or losses of whole chromosomes or segments were noticed in the root tips of a few plants. Chromosomes of all three species and several plant types were affected. There is no evidence that any one type of plant is especially unstable. Aberrant cells were usually rare and no mutation was found in both root tips and flowers. It is unlikely that such mutations have led to mis-classification of karyotypes in this study, for usually more than one root tip was examined from each plant.

The Gr.3 Gr.2 plant in L. hispidus shows fragmentation in a few p.m.c.'s (plate I $(a)$ ). Chromosome $\mathrm{C}_{3}$ was not present in either parent and must have arisen during the period of investigation. The interchange in the GI.3 Gr.2 plant was not seen in the GI.2 parent, but may come from the male parent, in which meiosis was not studied. The male parent is fully fertile, on both male and female sides, however, and so the interchange may be spontaneous. The results of crosses in L. hispidus suggest that deficiencies induce instability, for chromosome $\mathrm{G}_{3}$ also arose spontaneously from plants with different deficiencies.

\section{FREQUENCY AND SPATIAL DISTRIBUTION OF WILD VARIANT PLANTS}

The regional frequencies of variant plants and chromosomes in the pure species are given in tables I-6. Variant types may be common, uncommon or rare.

\section{(i) Common variants}

Chromosomes $\mathrm{C}_{2}, \mathrm{~F}_{2}$ and $\mathrm{F}_{3}$ in L. autumnalis and $\mathrm{B}^{\prime}$ in L. taraxacoides are common enough to constitute polymorphic variation sensu Ford (1940). In each chromosome type, the normal form represents about 9o per cent. of the aggregate total of chromosomes, but this does not hold for regional totals. The frequencies of the different zygotic types do not differ significantly from Hardy-Weinberg expectations $(P>0 \cdot I$ where $\chi^{2}$ test could be used).

Variation in satellite size is common, but seems to be continuous and hence not polymorphic. 
There is no obvious correlation between habitat and chromosome variation in any of the three species, but chromosomes $\mathrm{C}_{2}, \mathrm{~F}_{2}$ and $\mathrm{F}_{3}$ in L. autumnalis show different geographical distributions in the present samples. Normal plants are the commonest in all regions and in nearly all populations. No variant chromosome occurs in all populations, though chromosome $\mathrm{C}_{2}$ is found in all regions. Chromosome $\mathrm{F}_{2}$ has not been found in N.W. Britain or N. Europe, but it does occur in C. Europe. Ghromosome $\mathrm{F}_{3}$ has been found in N.W. Britain and N. Europe, but not in C. Europe. All three chromosomes can co-exist in the same population and all reach their highest frequency in S.E. Britain, where about 64 per cent. of plants contain at least one variant chromosome and nine different karyotypes are found. In N.W. Britain, only about 15 per cent. of plants are variant and only three different karyotypes are known (neglecting the Er.3 and interchange plants).

\section{(ii) Uncommon and rare variants}

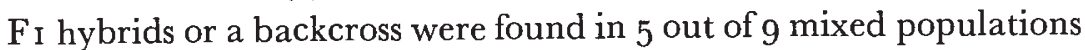
of L. taraxacoides and L. hispidus (see "Population samples"). Such plants are probably uncommon but widespread (see "Discussion").

In L. taraxacoides, triploidy is uncommon ( 3 out of $9^{2}$ plants) but may constitute a polymorphism (see "Discussion"). In L. hispidus, only I of the 82 plants sampled was triploid.

Chromosomes $\mathrm{E}_{2}$ and $\mathrm{E}_{3}$ in L. autumnalis, chromosomes $\mathrm{A}_{2}, \mathrm{C}_{2}$, $\mathrm{F}_{2}$ and $\mathrm{G}_{2}$ in $L$. hispidus and interchange chromosomes in all three species have been found only heterozygous and in one plant each.

Meiotic studies reveal inversion bridges in perhaps 2 out of 22 plants in L. autumnalis, in 2 out of 15 plants in L. taraxacoides (fig. $6(b)$ shows both types) and in I out of 9 plants in $L$. hispidus. Paracentric inversions are usually detectable only in heterozygotes and at meiosis and so their frequency cannot be accurately estimated from the present evidence.

\section{DISCUSSION}

\section{(i) Selective values of polymorphic chromosomes}

Polymorphic chromosome types in L. autumnalis are widespread and the polymorphism is probably ancient and balanced. Each rearranged chromosome type must have had a positive selective value to have survived to spread. Distal localization of chiasmata obviates their effects on meiotic recombination and so rearranged chromosomes must owe their original success to $(a)$ position effects of rearrangements, or (b) gene mutations or small losses or gains of chromatin arising in chiasma-free segments at or near the time of rearrangement, or $(c)$ both. It is unlikely that the rearranged chromosomes arose before chiasma-localization since the initial heterozygotes would probably have then been partly sterile.

L. autumnalis is self-incompatible, has a good means of dispersal, 
forms large populations and is nearly panmictic. The observed agreement of the frequencies of the different karyotypes with HardyWeinberg expectations, if stable and not due to sampling error, shows that either (I) each chromosome type is now selectively neutral compared with any other or (2) selection acts on each type in different ways either at different times or in different places or both, so that its opposite effects nullify one another.

The frequency differences shown by each chromosome type in S.E. and N.W. Britain suggest that each type now has a different selective value in each region, but it is uncertain how far this situation is complicated by accumulated genetic heterogeneity within types. Heterogeneity is visible in chiasma-free segments of chromosomes $\mathrm{E}$ and $F_{I}$ as variation in satellite size. The lack of similar variation in chromosomes $\mathrm{F}_{2}$ and $\mathrm{F}_{3}$ suggests that they are younger forms than $\mathrm{F}_{\mathrm{I}}$.

The B-B' polymorphism in $L$. taraxacoides is also widespread and probably balanced. Recombination of any genetic variation within the extra segment of the $B^{\prime}$ chromosome type should occur if plants disomic for chromosome $\mathbf{B}^{\prime}$ are viable.

\section{(ii) Frequency of polyploids}

As is usual in the Cichorieae (Stebbins et al., 1953), polyploidy is rare in Leontodon. Vaarama (unpublished, cited in Löve and Löve, I948) reported a tetraploid in $L$. autumnalis, but the triploids reported in the present paper are the only other polyploids known in the genus.

Triploids in $L$. taraxacoides and $L$. hispidus probably persist in nature once they are established. The experiments with $L$. taraxacoides show that triploids are slightly more vigorous than diploids and, although greatly reduced in fertility, can probably produce enough triploids in their progeny to maintain themselves as a polymorphism at low frequency. Triploids in L. hispidus are probably similar, but their meiosis is not likely to give as many diploid gametes (from which triploid progeny can arise) because of the higher chromosome number.

(iii) Formation of meiotic bridges and fragments in the F1 hybrid

Anaphase bridges and fragments in the $F_{I}$ hybrid are probably formed more often by spontaneous breakage and reunion than by normal chiasma-formation within relatively inverted segments. Evidence for this is as follows.

(I) Fragments may occur without bridges.

(2) Some new chromosome types in hybrid gametes cannot be accounted for by known types of chiasmate association.

(3) L. hispidus chromosomes $\mathrm{A}$ and $\mathrm{B}$ have been seen to form a bridge and fragment (fig. $8(d)$ ) but never to form a chiasma with each other.

(4) Bridges occur too often, compared with chiasmata, to be plausibly ascribed to inversion crossing-over.

Point (4) suggests that most bridges are formed irregularly, but 
the following three points allow the belief that some are due to normal inversion crossing-over.

(1) At the least, bridge-formation requires 2 breaks and I reunion, whereas the production of a fragment requires simply I break. Therefore, if bridge-formation be spontaneous, cells with fragments but not bridges should be commoner than those with bridges as well. The reverse is the case and so either single spontaneous breaks are usually masked by reunion, whereas double breaks reunite to form bridges, or else some bridges are due to normal inversion crossing-over.

(2) Assuming that unbroken ends cannot reunite with others, spontaneous bridge-formation must initially leave 2 fragments; but no bridge has been seen to be certainly associated with more than $\mathrm{I}$. This may be because the 2 fragments always reunite, but it could again be that normal inversion crossing-over occurs.

(3) Most bridges resemble chiasmata in being intergenomic.

All points are weakened by the small sizes of the p.m.c. samples and the first 2 are weakened by the possibility that some fragments have been overlooked in crowded cells.

\section{(iv) Importance of gene flow between L. taraxacoides and L. hispidus}

Probably all mixed populations of $L$. taraxacoides and $L$. hispidus contain a few $F_{1}$ hybrids, for the latter are easily formed and healthy. The low fertility of the F I obviously limits the amount of backcrossing severely, but the failure to detect more than one backcross in the wild may be due to the close morphological and chromosomal similarity to the species parents which backcrosses can show. McNaughton and Harper (I96o, II, III) have stressed that hybrids and backcrosses in Papaver may easily be overlooked.

The F I hybrid could be an important source of variation to each species because of the unusual types of meiotic recombination which are revealed in its gametes. Chromosome $B^{\prime}$ may have come from such a source and backcross clone ${ }_{5} 5$ (fig. Io $(a),(b)$ ) shows 2 bivalents which are similar to a $\mathrm{BB}^{\prime}$ bivalent. There is no sign in Leontodon of the remarkable partial elimination of the paternal chromosomes found by Ono (1957, 1958) in hybrids between Paraixeris, Lactuca and Crepidiastrum.

\section{SUMMARY}

I. Chromosomes in natural populations of Leontodon autumnalis $(\mathrm{n}=6)$, L. taraxacoides $(\mathrm{n}=4)$ and $L$. hispidus $(\mathrm{n}=7)$ vary in respect of pericentric rearrangements, paracentric inversions, interchanges and losses and gains of chromatin. Triploids occur in L. taraxacoides and L. hispidus.

2. Three pericentric rearrangements in L. autumnalis are probably ancient, balanced polymorphisms being common to British and European populations. One chromosome in L. taraxacoides shows probably balanced polymorphism for an extra intercalary segment 
which may have come from another species. Variation in satellite size is widespread in all three species, but is continuous and hence not polymorphic. Except perhaps for triploidy in L. taraxacoides, all other types of variation are too rare to constitute polymorphism.

3. L. taraxacoides and L. hispidus hybridize reciprocally. Fi hybrids and a backcross were detected in nature. The hybrid has irregular meiosis and is nearly sterile, but if backcrossed with either species, it gives a range of plants with different chromosome numbers and various degrees of meiotic irregularity and seed sterility. Several backcrosses have chromosome types not found in either species.

4. In variant and hybrid plants, unbalance due to aneuploidy sterilizes pollen but not eggs. At least one deficiency chromosome is transmissible through pollen and another through the egg.

5. Chromosome variation may affect the phenotype, as in triploids and most aneuploids and in most derivatives of species crosses, or it may be cryptic as in most plants with deficiencies and all with inversions or interchanges and in some derivatives of species crosses.

The evidence suggests that concealed gene flow occurs both ways between $L$. taraxacoides and L. hispidus in nature.

Acknowledgements.- I am grateful to Professor C. D. Darlington and Mr G. G. Vosa for their advice and encouragement during the course of this study, and to the Trustees of the Druce Bequest for financial support.

\section{REFERENCES}

Elliot, Eveline. I950. A new phase of amphiplasty in Leontodon. Nere Phytol., $49,344-349$.

FINCH, R. A. I966. Chromosomal and morphological variation in the British flora. D. Phil. thesis, Oxford. (In library of Botany School, Oxford.)

FORD, E. B. I940. Polymorphism and Taxonomy. The New Systematics, ed. Huxley, J. Clarendon Press, Oxford, 493-513.

LÖVE, A., AND LÖVE, D. I948. Chromosome Numbers of Northern Plant Species. Reykjavik Univ. Inst. App. Sci. Dept. Agric. Rep., B, 3, I 33 pp.

MCNAUGHTON, I. H., AND HARPER, J. L. I960. The comparative biology of closely related species living in the same area. II. Aberrant morphology and a viruslike syndrome in hybrids between Papaver rhoeas L. and $P$. dubium L. New Phytol., 59, 27-4I. III. The nature of barriers isolating sympatric populations of Papaver dubium and P. lecoqii. Newe Phytol., 59, 129-1 37.

ono, H. 1957. Intergeneric Hybrid Swarms in Cichorieae. Cytologia suppl. Proc. int. Genet. Symp., 1956, 380-383.

ono, H. 1958. Chromosome Breakage induced by Hybridization. $X$ int. Cong. Genet. Proc., II, 209.

Stebbins, G. L. JR., Jenkins, J. A., AND walters, marta, s. i953. Chromosomes and Phylogeny in the Compositae, Tribe Cichorieae. Univ. Calif. Publs. Bot., 26, 40 I-429.

vosA, G. G. Ig6I. A modified aceto-orcein method for pollen mother cells. Caryologia, I4, IO7-I IO.

WHITE, M. J. D., AND MORLEY, F. H. W. I955. Effects of pericentric rearrangements on recombination in grasshopper chromosomes. Genetics, Princeton, 4o, 6o4-6r 9 . 


\section{Plate I}

(a) Diakinesis in $L$. hispidus $\mathrm{CI}_{\mathrm{I} .3} \mathrm{Gr}_{\mathrm{I} .2}$ plant. $6 \mathrm{II}+$ small $\mathrm{I}+$ fragment. $\times \mathrm{I}, 600$ (b)-(d) L. taraxacoides-L. hispidus $\mathrm{F}_{\mathrm{I}}$ hybrid, acetic alcohol fixation.

(b) Pachytene. $\times 1,600$

(c) MI with (?) chain of $3+2 \mathrm{II}+4$ I. $\times 3,200$

(d) MI with (?) 2 chains of $5+$ I. $\times 4,000$

(e) L. autumnalis: MI in normal plant, acetic alcohol fixation. $\times 3,300$. 

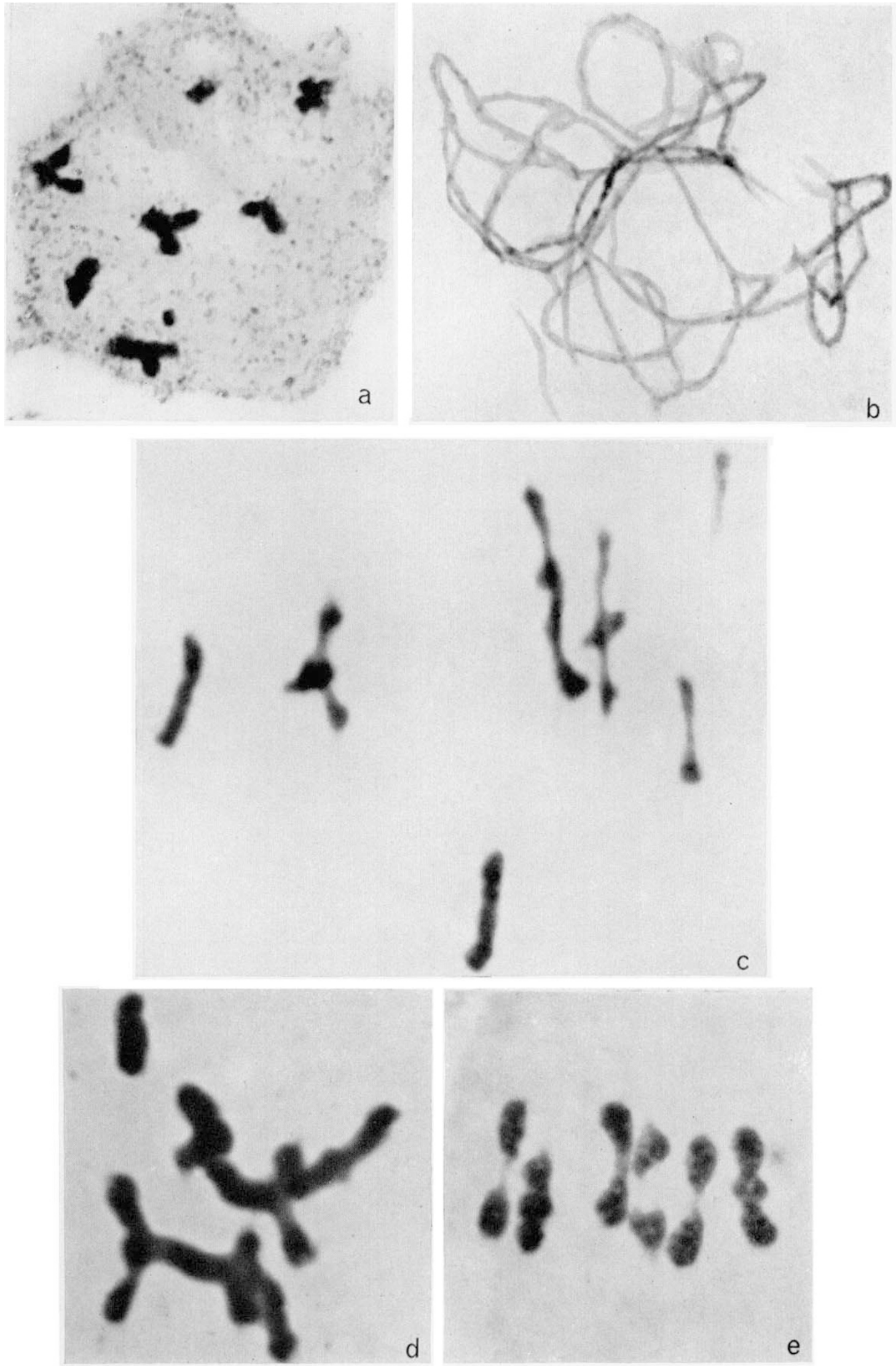